\title{
Nanoparticles in tissue engineering: applications, challenges and prospects
}

This article was published in the following Dove Press journal:

International Journal of Nanomedicine

\author{
Anwarul Hasan' \\ Mahboob Morshed ${ }^{2}$ \\ Adnan Memic ${ }^{3}$ \\ Shabir Hassan ${ }^{4,5}$ \\ Thomas J Webster 6 \\ Hany El-Sayed Marei ${ }^{7}$ \\ 'Department of Mechanical and \\ Industrial Engineering, Qatar \\ University, Doha, Qatar; ${ }^{2}$ School of \\ Life Sciences, Independent University, \\ Bangladesh (IUB), Dhaka, Bangladesh; \\ ${ }^{3}$ Center of Nanotechnology, King \\ Abdulaziz University, Jeddah, Saudi \\ Arabia; ${ }^{4}$ Division of Engineering in \\ Medicine, Department of Medicine, \\ Brigham and Women's Hospital, \\ Harvard Medical School, Boston, \\ MA, USA; ${ }^{5}$ Harvard-MIT Division \\ of Health Sciences and Technology, \\ Massachusetts Institute of Technology, \\ Cambridge, MA, USA; ${ }^{6}$ Department of \\ Chemical Engineering, Northeastern \\ University, Boston, MA, USA; \\ ${ }^{7}$ Biomedical Research Center, Qatar \\ University, Doha, Qatar
}

\begin{abstract}
Tissue engineering (TE) is an interdisciplinary field integrating engineering, material science and medical biology that aims to develop biological substitutes to repair, replace, retain, or enhance tissue and organ-level functions. Current TE methods face obstacles including a lack of appropriate biomaterials, ineffective cell growth and a lack of techniques for capturing appropriate physiological architectures as well as unstable and insufficient production of growth factors to stimulate cell communication and proper response. In addition, the inability to control cellular functions and their various properties (biological, mechanical, electrochemical and others) and issues of biomolecular detection and biosensors, all add to the current limitations in this field. Nanoparticles are at the forefront of nanotechnology and their distinctive size-dependent properties have shown promise in overcoming many of the obstacles faced by TE today. Despite tremendous progress in the use of nanoparticles over the last 2 decades, the full potential of the applications of nanoparticles in solving TE problems has yet to be realized. This review presents an overview of the diverse applications of various types of nanoparticles in TE applications and challenges that need to be overcome for nanotechnology to reach its full potential.

Keywords: nanoparticles, tissue engineering, antibacterial applications, mechanotransduction, gene delivery
\end{abstract}

\section{Introduction}

Tissue engineering (TE) is the study of the growth of new tissues and organs, starting from a base of cells and scaffolds. ${ }^{1,2}$ The scaffolds are used as three-dimensional (3D) structures in which cells grow, proliferate and differentiate into various cell types. Growth factors are introduced into the scaffolds to direct cell behavior toward any desired process where the eventual goal is to produce fully functional organs or tissues capable of growth and regeneration and suitable for implantation. ${ }^{3,4}$ Despite such promises, TE faces numerous limitations; transcribing these ideas into reality seems like an uphill task. The inability of engineered materials to mimic the natural properties of tissues is one of the roadblocks. Nanotechnology through customized nanoparticle engineering has the potential to solve this challenge. ${ }^{4,5}$

Nanoparticles are characterized by their nanoscale dimension, enabling them to develop critical physical and chemical characteristics that enhance their performance and therefore make them beneficial for a wide range of applications. ${ }^{6}$ In the biomedical field, nanoparticles have been used for controlled drug delivery, ${ }^{7,8}$ imaging of specific sites, probing of DNA structures, ${ }^{9-11}$ biomolecular sensing, gene delivery, photothermal ablation of cells ${ }^{12}$ and, most recently, TE. ${ }^{13,14}$ Additionally, many therapies utilize nanoparticles for the treatment of cancer, ${ }^{15}$ diabetes, ${ }^{16}$ allergy, ${ }^{17}$ infection ${ }^{18}$ and inflammation. ${ }^{19}$
Correspondence: Anwarul Hasan

Department of Mechanical and Industrial Engineering, Qatar University, Doha 27I3, Qatar

Tel +97470569169

Email hasan.anwarul.mit@gmail.com 
Very recently, nanoparticles have been used in TE in order to obtain improved mechanical and biological performances..$^{20}$ The surface conjugation and conducting properties of gold nanoparticles (GNPs), the antimicrobial properties of silver and other metallic nanoparticles and metal oxides, the fluorescence properties of quantum dots and the unique electromechanical properties of carbon nanotubes (CNTs) have made them very useful in numerous TE applications. In addition, magnetic nanoparticles (MNPs) have been applied in the study of cell mechanotransduction, gene delivery, controlling cell patterning and construction of complex 3D tissues.

The advantage of nanoparticles in TE stems from their small size and their associated large surface to volume ratio, which is comparable to peptides and small proteins. They can easily diffuse across membranes and facilitate uptake by cells. Moreover, one is not limited by a predetermined size for nanoparticles, since they can be made in customized sizes and surface characteristics in order to suit any purpose. Nanoparticles also mimic the natural nanometer size scale of extracellular matrix (ECM) components of tissues themselves.

In one sense, nanoscale structures can be considered as an integral part of our body where the components of organs and tissues such as ECM and cells comprise various atoms, molecules, nanostructures, microstructures and macroscale structures hierarchically.

On the other hand, there are numerous external nanoparticles that enter and exit our body frequently through the inhaled air or oral and topical routes, which depending on the toxicity or nature of the particle may or may not be harmful to the body. A third source of nanoparticles in our body could be the release or secretion of elements from biomedical prosthetics and implants transplanted in our body. As reported in several studies, ${ }^{21-23}$ metal nanoparticles, namely, $\mathrm{Ag}, \mathrm{Cr}, \mathrm{Fe}, \mathrm{Mo}, \mathrm{Ni}, \mathrm{Ta}, \mathrm{Cr}, \mathrm{Co}, \mathrm{Sb}$ and $\mathrm{Sc},{ }^{22}$ were formed both in tissues adjacent to the implants and distant to the implantation sites after implementation of bioprosthetics in the body. A high accumulation of metallic elements was found in the brain and lungs of patients with hip endoprosthesis, while hip arthroplasty patients were found to exhibit high concentrations of $\mathrm{Cr}$, Co and Mo ions in their hair as well. ${ }^{24}$ These three types of nanoparticles mentioned earlier are beyond the scope of this review.

In this review, we present an overview of the diverse applications of various types of nanoparticles in TE applications. This review addresses the applications of magnetic, metallic, ceramic and metal oxide nanoparticles in TE. They are advantageous, as they tend to be biocompatible and have low immunogenicity. The specific intrinsic properties of each material may hold the answer to overcoming the current hurdles in TE, where the use of materials engineering has not been exploited to its full potential. The insights provided in this review will be beneficial for material scientists and tissue engineers working with nanoparticles, allowing them to navigate through applications that best fit their need.

\section{Brief background of nanoparticles}

Nanoparticles are entities of any shape with a size range of 1-100 nm in any one dimension. ${ }^{25}$ Such a unique size gives these particles the properties of both bulk materials and molecular structures. As such, nanoparticles are viewed as the "bridge" between the macroscopic and microscopic structures. Their small size gives them one of their most attractive intrinsic properties: a high surface to volume ratio. Nanoparticles are highly mobile when they are in a free state, causing them to have tremendously slow sedimentation rates (Figure 1). In addition, they are characterized by a wide range of compositions ranging from soft to hard materials depending on their use and may exhibit what is known as the quantum effect. This quantum effect allows one to have extreme control over the surface energy of these particles, which in turn can control initial protein adsorption to dictate cellular interactions. ${ }^{26}$

Depending on the shape, nanoparticles can be of $0 \mathrm{D}$, 1D, 2D or 3D structure types. ${ }^{27,28}$ Based on their source or type of materials, they can be divided into different categories such as carbon-based, metal-based, ceramic-based, polymeric-based, semiconductor-based and lipid-based nanoparticles. ${ }^{28}$ Nanoparticles can be synthesized by using two main methods such as 1) bottom-up and 2) top-down approaches. ${ }^{29}$ Furthermore, these methods can be divided into mechanical, chemical and biological syntheses, ${ }^{30}$ and these include chemical vapor deposition, physical vapor deposition, a sol-gel method, radio frequency (RF) plasma method, pulsed laser method, thermolysis and solution combustion method. Various characterization methods used to characterize the nanoparticles depend on the property of the materials. The morphology of the nanoparticles has been analyzed using polarized optical microscopy (POM), scanning electron microscopy (SEM), transmission electron microscopy (TEM), atomic force microscopy (AFM), X-ray photoelectron spectroscopy (XPS), infrared (IR), X-ray diffraction (XRD), Raman spectroscopy, Brunauer-EmmettTeller (BET) and Zeta size analyzer. ${ }^{30,31}$

These properties provide unique applications of nanoparticles in a wide variety of research fields, eg, biomedical sciences, electronics, optics and more. While significant progress has been made for numerous nanoparticle applications in 
A

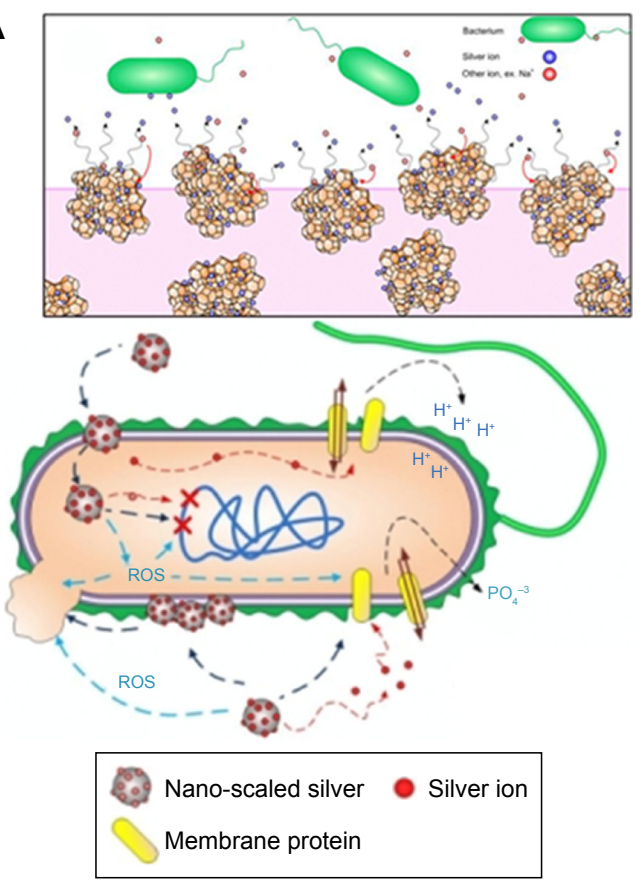

$\mathbf{E}$

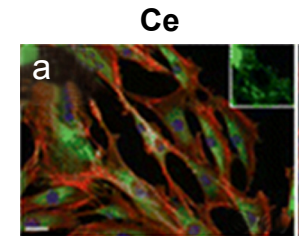

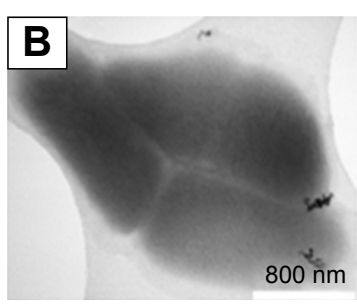
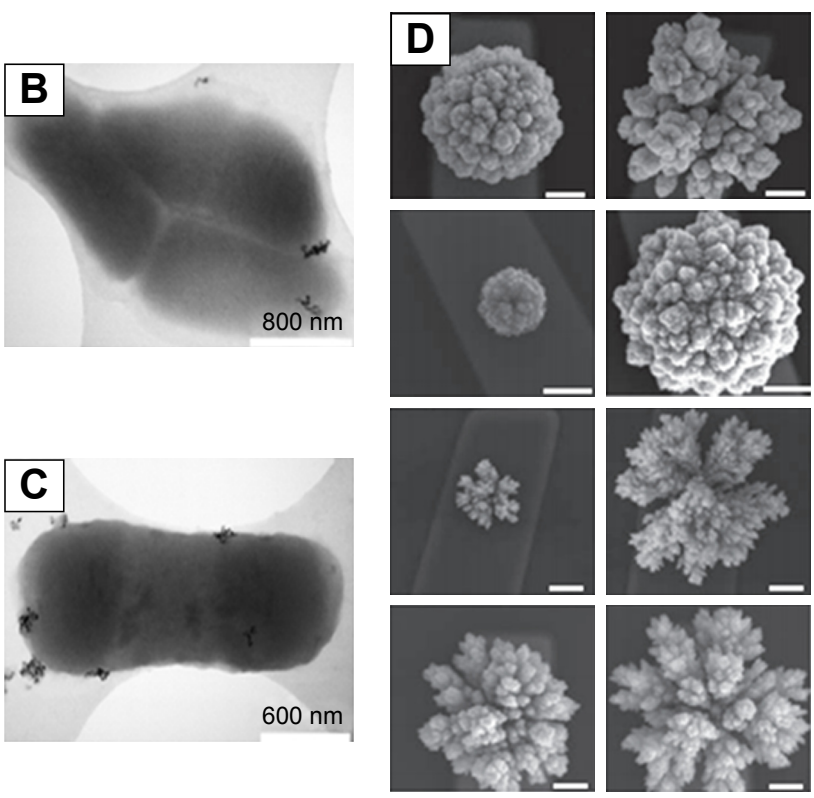

Figure I Interaction of bacteria and mammalian cells with nanoparticles.

Notes: (A) Schematics of the effects of nanoparticles on bacterial cells. (B and $\mathbf{C}$ ) Representative electron microscopy images showing the interaction of $E$. coli with the samples of cerium oxide nanoparticles at different magnifications. (D) Programmable nanomaterial synthesis using GNPs under different deposition parameters. (E) Effects of $\mathrm{CeO}_{2}$ nanoparticles on cardiac progenitor cell morphology and growth. $\mathrm{CeO}_{2}$-untreated (a) or $\mathrm{CeO}_{2}$-treated cells $10 \mu \mathrm{g} / \mathrm{mL}$ (b), $25 \mu \mathrm{g} / \mathrm{mL}$ (c) and $50 \mu \mathrm{g} / \mathrm{mL}$ (d). (A-C) Republished with permission of American Society for Microbiology, from Effects of engineered cerium oxide nanoparticles on bacterial growth and viability. Pelletier DA, Suresh AK, Holton GA, et al. Appl Environ Microbiol. 76(24):798I-7989. Copyright 2010. ${ }^{167}$ (D) Reprinted by permission from Springer Nature: Nat Nanotechnol. Programming the detection limits of biosensors through controlled nanostructuring. Soleymani L, Fang Z, Sargent EH, Kelley SO. Copyright 2009. ${ }^{168}$ (E) Reprinted with permission from Pagliari F, Mandoli C, Forte G, et al. Cerium oxide nanoparticles protect cardiac progenitor cells from oxidative stress. ACS Nano. 20I2;6(5):3767-3775. Copyright 20I2 American Chemical Society. ${ }^{169}$

Abbreviations: E. coli, Escherichia coli; GNP, gold nanoparticle; ROS, reactive oxygen species.

these fields, their applications in TE are still in their infancy stage hindered by some significant challenges. Here, we aim to review the application of nanoparticles in TE along with the challenges associated with them and address how such challenges can be tackled widening the application of nanoparticles in a broad range of TE applications.

\section{Applications of nanoparticles in TE}

Nanoparticles have been used to serve various functions in TE, ranging from enhancement of biological, electrical and mechanical properties to gene delivery, DNA transfection, viral transduction and patterning of cells, to facilitate the growth of various types of tissues to molecular detection and biosensing. The use of the right type of nanoparticles in TE can significantly enhance the biological, mechanical and electrical properties of scaffolds as well as can serve various functions depending on the applications ${ }^{32}$ as described in the following.

\section{Biological property enhancement: increased cell proliferation rates}

In particular, two types of nanoparticles, namely, GNPs and titanium dioxide $\left(\mathrm{TiO}_{2}\right)$ nanoparticles, have been used to enhance cell proliferation rates for bone and cardiac tissue regeneration, respectively. GNPs have shown superior biocompatibility and the ability for surface modification, which has resulted in interesting biomedical applications. ${ }^{33,34}$ In bone TE, it was first observed that GNPs promote osteogenic differentiation of an osteoblast precursor cell line, MC3T3-E1.35,36 In addition, these nanoparticles also influenced osteoclast (or bone resorbing cell) formation from hematopoietic cells while providing protective effects 
on mitochondrial dysfunction in osteoblastic cells..$^{37,38}$ Another report showed that GNPs can promote osteogenic and adipogenic differentiation of mesenchymal stem cells (MSCs). This happened after their intracellular uptake during the establishment of the $\mathrm{p} 38$ mitogen-activated protein kinase (MAPK) pathway. ${ }^{38}$ It was found, however, that this osteogenic differentiation is dependent on the size of GNPs. One study demonstrated that GNPs of diameters $30-50 \mathrm{~nm}$ were favorable and more effective for human adipose-derived stem cell (ADSC) function, ${ }^{37}$ while another study showed a preference for 20 and $40 \mathrm{~nm}$ sized GNPs for MC3T3-E1 osteoblast-like cell function. ${ }^{39}$

In light of these studies, GNPs present themselves as excellent candidates for bone tissue regeneration. They seem to be perfect candidates to replace bone morphogenetic proteins (BMPs). Although BMPs have beneficial effects on bone regeneration and repair, ${ }^{40,41}$ they also have many disadvantages. Their high cost and susceptibility to result in unwanted bone formation and local inflammatory reactions are some of the main reasons that have prompted researchers toward the search for alternative bone growth materials, and GNPs may be a promising substitute. ${ }^{42-44}$ Numerous papers have reported promising in vitro experimental results using GNPs. However, there were considerable variations in the experimental results when carried out in animals.

To overcome this, hybrid scaffolds (GNPs and gelatin) were studied under in vivo conditions for their effectiveness in initiating osteogenic differentiation consequent to human ADSCs. The hydrogels were placed in the parietal bone of rabbits, where bone defects were made prior to the application of the hydrogel. The study showed enhanced proliferation of osteoblasts as the GNP content in the hydrogels increased. ${ }^{44}$

In other studies, GNPs and gold nanowires placed within a scaffold had a remarkable impact on cell proliferation and synapse formation, which is the key to a functional organ transplant. Additionally, these materials may also direct stem cell differentiation, without using growth factors, thus minimizing/avoiding the numerous side effects of the application of growth factors in the body. ${ }^{45,46}$

GNPs have also been successfully used to produce a favorable cellular environment for cardiac TE applications. GNP-loaded nanofibers led to the enhancement of cardiomyogenic differentiation to help infarcted myocardium regeneration. ${ }^{47}$

In another study, $\mathrm{TiO}_{2}$ nanoparticles were added to the scaffold in which human embryonic stem cell-derived cardiomyocytes showed enhanced cell proliferation. ${ }^{48} \mathrm{TiO}_{2}$ nanoparticles have also been 3D printed with polymers, such as poly(lactic-co-glycolic acid) (PLGA) to exactly match the nanostructured roughness of bone itself and significantly improve bone cell performance. ${ }^{49}$ Interestingly in this study, the $\mathrm{TiO}_{2}$ nanoparticles were also shown to decrease the harmful effects of acid byproducts released by PLGA during degradation, which are known to kill cells. ${ }^{49}$ Thus, incorporation of certain types of nanoparticles into scaffolds can significantly alter the biological properties of scaffolds and thus help in TE.

\section{Enhancement of mechanical properties}

Nanoparticle-embedded nanocomposite polymers both in the form of hydrogels and electrospun fibers have exhibited superior mechanical properties for TE applications compared to scaffolds without nanoparticle reinforcements. ${ }^{50-52}$ For example, a $\mathrm{TiO}_{2}$-embedded biodegradable patch showed a higher tensile strength in reinforcing the scar after myocardial infarction..$^{53}$ In another study, hydrogel microfibers with poly ( $N$-isopropylacrylamide) (PNIPAm) and MNPs increased the mechanical strength of hydrogel microfibers. ${ }^{54}$ Introducing attapulgite nanoparticles enhanced the mechanical properties of chitosan/ $\beta$-glycerophosphate disodium salt (CS/GP) injectable hydrogels. ${ }^{55}$ Attapulgite amplified the cross-links because of the hydrogen bonds that were formed between attapulgite nanoparticles and CS molecules. It showed five times larger tensile strength and elongation compared to the neat CS/GP hydrogel at break. ${ }^{55}$

For skin TE, 3D nanocomposite scaffolds were prepared using a mixture of type I collagen and polyvinylpyrrolidone (PVP)-coated $\mathrm{TiO}_{2}$ nanoparticles. In this mixture, hydrogen bonds were formed between collagen, $\mathrm{PVP}$ and $\mathrm{TiO}_{2}$, which improved the ultimate tensile strength of the scaffolds. ${ }^{56,57}$ In other studies, GNPs, silver nanoparticles and MNPs were embedded in the scaffolds to improve the scaffold mechanics, ${ }^{58}$ while in some studies, hydroxyapatite (HA) nanoparticles enhanced the mechanical properties of electrospun silk fibroin scaffolds by making bonds between HA and silk fibroin fibers. ${ }^{59}$ Thus, nanoparticles can play a vital role in enhancing the mechanical properties of scaffolds in TE.

CNTs have also been used to enhance the mechanical properties of polymers for TE applications ${ }^{60} \mathrm{CNTs}$ reinforce the polymers especially due to their remarkable mechanical properties, tensile strength and fiber-like structure. ${ }^{61,62}$ Recently, CNTs were added into polylactic acid (PLA) blends and were electrospun into nanofiber mats; it was found that they had amazing biocompatibility and osteoinductive potential as compared to PLA/gelatin nanofibers. The CNT-contained PLA nanofibers improved mechanical properties of the 
hybrid samples, and such a 3D system appears to be interesting for potential applications as a TE scaffold. ${ }^{63}$ The addition of CNTs in polycaprolactone (PCL), for example, increased the mechanical properties of PCL several folds when applied to enhance the proliferation and differentiation of rat bone marrow stem cells (BMSCs) ${ }^{64}$ Similarly, graphene-based nanoparticles have also been used in TE for the replacement of damaged connective tissue. For example, composites based on graphene oxide (GO) and silk fibroin showed improved proliferation, adhesion and viability of human periodontal ligament mesenchymal stem cells (PDLSCs) as compared to silk fibroin alone. ${ }^{65}$ In other studies, graphene-based nanomaterials of stem cells enhanced the proliferation, attachment and osteogenic differentiation for bone regeneration in addition to improvement of mechanical properties. ${ }^{66-68}$

In one study, composites of a cyclic copolymer (COC) also termed as TOPAS and HA were synthesized for bone repair and regeneration. HA nanoparticles were uniformly dispersed inside the TOPAS copolymer, and improved mechanical properties were reported due to better dispersion and interfacial interactions with HA chains. Preosteoblasts showed improved cell adhesion and proliferation on TOPAS/ HA hybrids as compared to TOPAS alone. An improvement in biomedical potential was cited due to improved mechanical properties of TOPAS/HA composites compared to TOPAS alone. ${ }^{69}$ In another study, silk fibers were incorporated into chitosan/glycerophosphate hydrogels to enhance the mechanical capacity of the constructs that could be applied for hyaline cartilage regeneration. The newly developed chitosan/glycerophosphate reinforced with silk fibers not only showed improved mechanical properties but also manifested enhanced proliferation potential of chondrocytes on these scaffolds. ${ }^{70}$ Similarly, $\mathrm{CaCO}_{3}$ nanoparticles were incorporated into chitosan/poly(vinyl alcohol) (PVA) blends to improve the mechanical properties of the electrospun nanofiber mats. Chitosan/PVA nanofibers showed increased tensile strength and biocompatibility when the concentration of $\mathrm{CaCO}_{3}$ varied from 1 to $5 \mathrm{wt} \%$. In addition, the reinforcement of chitosan/PVA nanofiber scaffolds with $4 \% \mathrm{CaCO}_{3}$ proved to be effective scaffolds for ATDC5 cell proliferation and provided a positive environment for cell growth as compared to chitosan/PVA and chitosan/PVA-apatite nanoformulations. Therefore, chitosan/PVA/ $\mathrm{CaCO}_{3}$ nanofibers showed promising artificial leads for cartilage tissue regeneration. ${ }^{71}$

\section{Enhancement of electrical properties}

Various nanoparticles have been used to enhance the electrical properties of scaffolds, which can be highly beneficial in cardiac TE. ${ }^{47}$ In one study, when depositing GNPs into fibrous decellularized matrices, cardiac cells within the scaffolds exhibited improved morphology, better striation behavior and enhanced electrical coupling proteins. This study provided promising results for engineering cardiac patches with nanoparticles to treat myocardial infarction. ${ }^{72}$

Similar studies were carried out using gold nanostructures, which were integrated into scaffolds to boost matrix conductivity and develop an electrical signal between different cardiac components. GNP-based electrospun fibrous scaffolds were reported to be functional for cardiac tissue regeneration. GNPs were deposited on the surface of the gelatin and PCL-gelatin fibers, creating nanocomposites with a nominal gold thickness that showed that cardiac tissues engineered within these GNP scaffolds can be used to improve the function of the infarcted heart. ${ }^{73-75}$

Gold nanowires have also been used as conductive materials alongside scaffolds to enhance the electrical coupling between the cells. With time, cardiac muscle cells started growing within the 3D porous scaffolds and resulted in synapse formation. ${ }^{76}$ Studies have also highlighted that the use of CNTs in polymer composites can significantly improve conductivity to promote cardiomyocyte functions; ${ }^{77}$ it is clear that conductive nanomaterials have a promising future in cardiac applications. Table 1 is designed to show the electrical conductivity of polymers and nanocomposites and their diverse applications in the biomedical field.

\section{Antibacterial applications}

Importantly, the Centers for Disease Control (CDC), USA, recently predicted more deaths from antibiotic-resistant bacteria than from all cancers combined by $2050 .{ }^{62,74,78,80-83}$ This has certainly highlighted the growing need to identify alternative means to kill bacteria without using antibiotics, and nanoparticles may provide the answer. ${ }^{84}$ Some metal oxides, particularly silver nanoparticles, have shown great antimicrobial effects, as well as wound healing capabilities (Figure 2A-D). ${ }^{85-89}$ Xing et $\mathrm{al}^{83}$ assessed the antibacterial activity of poly(3-hydroxybutyrate-co-3-hydroxyvalerate) (PHBV) nanofibrous scaffolds containing silver. It was found that silver-containing PHBV nanofibrous scaffolds had high antibacterial properties and they exhibited excellent in vitro cell compatibility. This shows that PHBV nanofibrous scaffolds containing silver nanoparticles have prospects to be used in joint arthroplasty and, thus, should be further studied. Another study dealt with the categorization and antimicrobial activity of a nanosilver-based biocomposite scaffold for bone TE. ${ }^{90}$ Results suggested that biocomposite 
Table I Electrical conductivity of nanocomposites and their applications in the biomedical field

\begin{tabular}{|c|c|c|c|c|}
\hline Polymer & $\begin{array}{l}\text { Polymers' } \\
\text { conductivity } \\
\left(\mathrm{S} \cdot \mathrm{cm}^{-1}\right) \text {, before } \\
\text { adding nanoparticles }\end{array}$ & Nanocomposites & $\begin{array}{l}\text { Nanocomposites' } \\
\text { conductivity } \\
\left(\mathrm{S} \cdot \mathrm{cm}^{-1}\right) \text {, after } \\
\text { adding nanoparticles }\end{array}$ & Applications \\
\hline Chitosan & $7.4 \times 10^{-9}$ & Chitosan/carbon & $3.08 \times 10^{-3}$ & Cardiac $\mathrm{TE}^{78}$ \\
\hline PANI & $10^{-3}$ & $\mathrm{PANI} / \mathrm{Ag}$ & $10^{-2}$ & TE and wound-healing applications ${ }^{67}$ \\
\hline Hydrogel & $0.23 \pm 0.02$ & Graphene/hydrogel & $4.9 \pm 0.2$ & TE applications ${ }^{79}$ \\
\hline PPy & $1.3 \times 10^{-5}$ & PPy/chitosan & $10^{-3}-10^{-7}$ & TE and wound-healing applications ${ }^{70}$ \\
\hline PPy & $1.3 \times 10^{-5}$ & PPy/cellulose acetate & $6.9 \times 10^{-4}$ to $3.6 \times 10^{1}$ & TE applications $s^{71}$ \\
\hline PANI & $10^{-3}$ & PANI nanofibers/collagen & 0.27 & $\begin{array}{l}\text { Scaffold material for biomedical } \\
\text { applications }{ }^{63}\end{array}$ \\
\hline PANI & $10^{-3}$ & PANI nanofiber/bacterial cellulose & $10^{-2}$ & Biosensors, $T^{63}$ \\
\hline PPy & $1.3 \times 10^{-5}$ & PPy nanoparticles/PU & $2.3 \times 10^{-6}$ & $\mathrm{TE}^{72}$ \\
\hline PPy & $1.3 \times 10^{-5}$ & PPy/poly(D,L-lactic acid) & $15.65 \times 10^{-3}$ & Synthetic nerve conduits ${ }^{74}$ \\
\hline PU & $8.8 \times 10^{-11}$ & PU/graphene & $>10^{-3}$ & Sensors, bone applications ${ }^{75}$ \\
\hline PMMA & $10^{-11}$ & PMMA/MWCNT & $10^{-5}$ & Devices for $\mathrm{TE}^{75}$ \\
\hline
\end{tabular}

Abbreviations: TE, tissue engineering; PANI, polyaniline; PPy, polypyrrole; PU, polyurethane; PMMA, polymethylmethacrylate; MWCNT, multiwalled carbon nanotubes.

scaffolds containing nanosilver could regulate bacterial infection during reconstructive bone surgery and that the presence of silver nanoparticles in the scaffolds acted as an affixed coating for protection against infection, sepsis and malfunctioning of implants.

In another study conducted by Marsich et al, ${ }^{91}$ antibacterial nanoscaffolds were developed by introducing silver nanoparticles to alginate and HA scaffolds. These scaffolds possessed enhanced antimicrobial properties, beneficial in prosthesis implementation. Patrascu et $\mathrm{a}^{92}$ also fabricated composite scaffolds with silver nanoparticles where collagensilver nanoparticle scaffolds were produced for skin repair, especially for burn victims, while composite HA-silver nanoparticles and HA/collagen-silver nanoparticle composite scaffolds were developed as potential bone graft materials. ${ }^{92}$ Silver nanoparticles have also been used with poly(L-lactideco-caprolactone) (PLCL) scaffolds for skin TE. The scaffolds were developed using electrospinning techniques. ${ }^{82}$ Similarly, silver nanoparticles were used in PCL composite scaffolds for in vitro tissue-engineered vascular grafts. ${ }^{93}$ The antimicrobial features of silver nanoparticles enabled their infusion into various composite scaffold materials such as HA, alginate, PLCL, PCL and collagen. ${ }^{82,91-94}$ However, recent studies have highlighted that bacteria may develop a resistance to silver nanoparticles, so extreme caution and additional studies should be undertaken for all of the abovementioned materials. ${ }^{95}$

Apart from silver nanoparticles, different metal oxide nanoparticles have also proven to be effective as bactericidal agents. Specifically, magnesium oxide nanoparticles and their halogen adducts with $\mathrm{Cl}_{2}$ and $\mathrm{Br}_{2}$ showed strong antibacterial properties. ${ }^{81}$ In order to assess the effectiveness of the nanoparticles, a study was performed by Stoimenov et al on three groups of bacteria: Escherichia coli, Bacillus megaterium and Bacillus subtilis. It was shown that the nanoparticulate formulations were able to destroy the populations of E. coli and B. megaterium bacteria in $\sim 20 \mathrm{~min}$.

There has also been excitement over the use of selenium nanoparticles since it has been shown that selenium kills bacteria by different mechanisms than the above mentioned nanoparticles, which rely on reactive oxygen species (ROS) ${ }^{96}$ It has been speculated that nanoparticles that rely on ROS generation to kill bacteria may lead to mutations of bacteria, thus causing the bacteria to be resistant to such materials. In contrast, selenium nanoparticles, which have been shown to kill both gram-positive and gram-negative bacteria (Figure 2E), alter thiol-containing protein function inside bacteria, for which bacterial resistance has not been reported. ${ }^{97}$

Furthermore, iron oxide nanoparticles have demonstrated much promise in killing post-biofilm formation in bacteria. ${ }^{98}$ Specifically, iron oxide nanoparticles (especially when functionalized with sugars such as fructose and sucrose) can penetrate biofilms, whereas antibiotics cannot, under a magnetic field to disrupt and kill bacteria (Figure 2F). ${ }^{99,100}$ This has enormous consequences in TE since currently if a biomaterial becomes infected, it needs to be removed and adjacent tissue cleaned. Strategies that do not rely on implant removal and cleaning can have a bright future in TE.

\section{Stimulation of cells for mechanotransduction}

It is well known that various bioactive molecules and growth factors regulate cell function in the human body. It has been shown that, in addition to these substances, mechanical forces play a major role in determining cell functions by affecting 


\section{A}

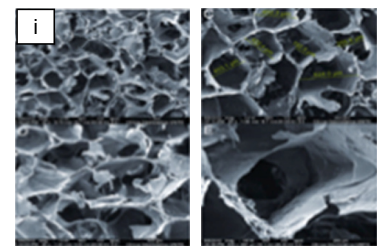

B
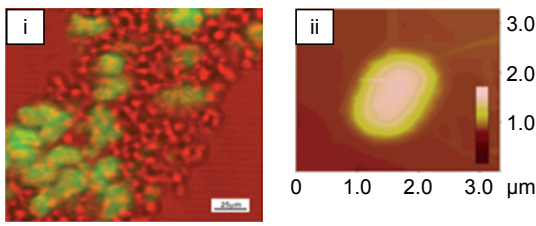

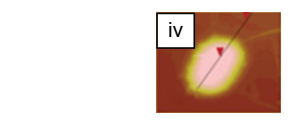

$\mathrm{nm}$

200

0

$-200$

D
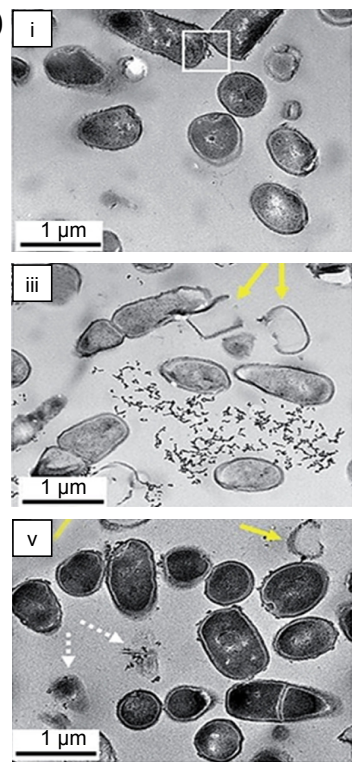

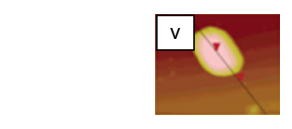

nm

500

$-500$
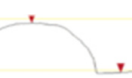

2.5

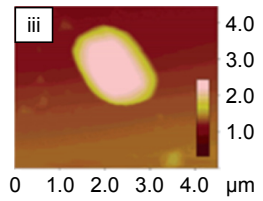

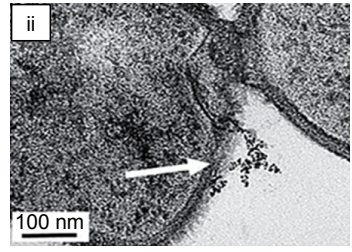

$\mathbf{E}$
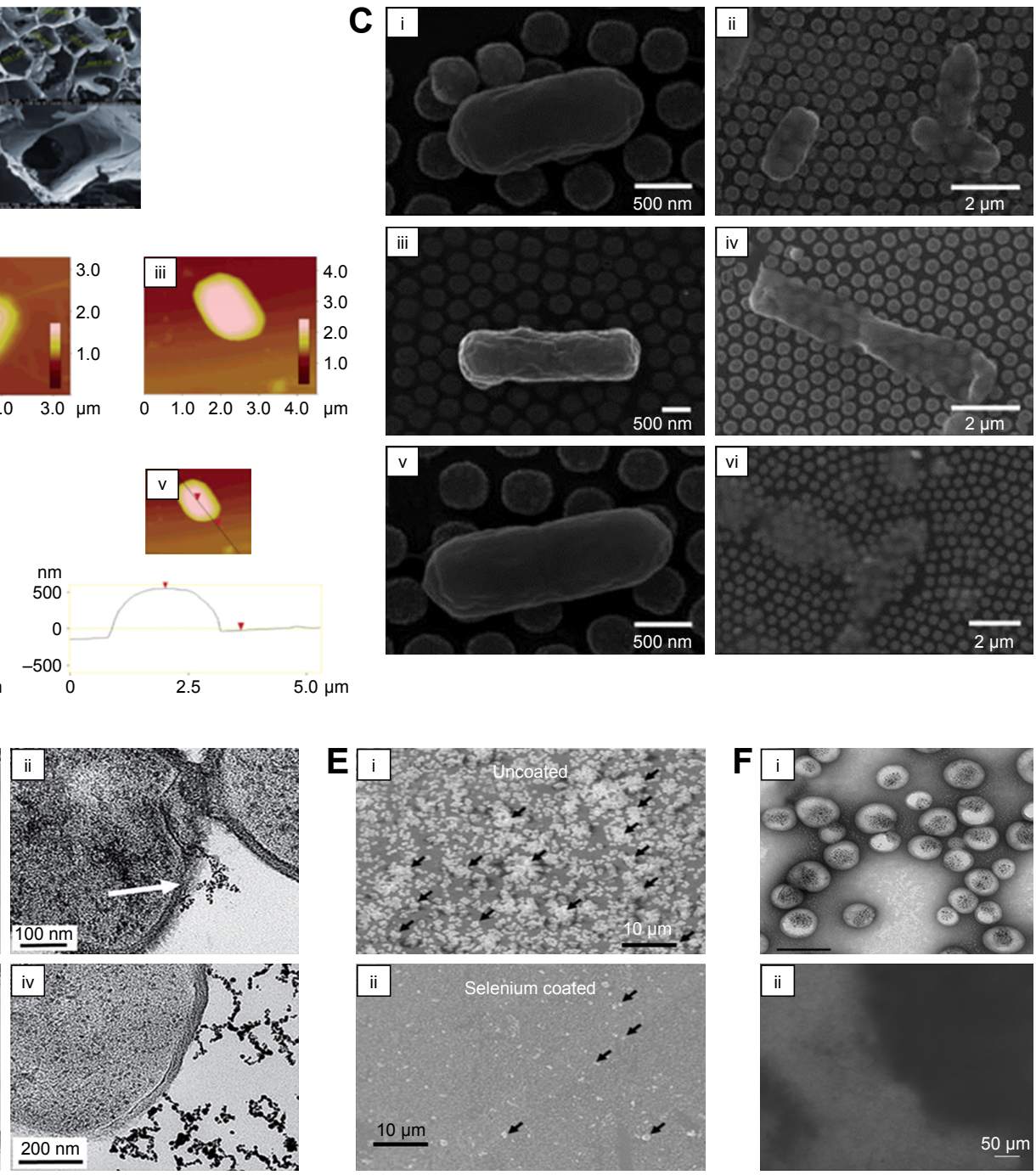

$5.0 \mu \mathrm{m}$
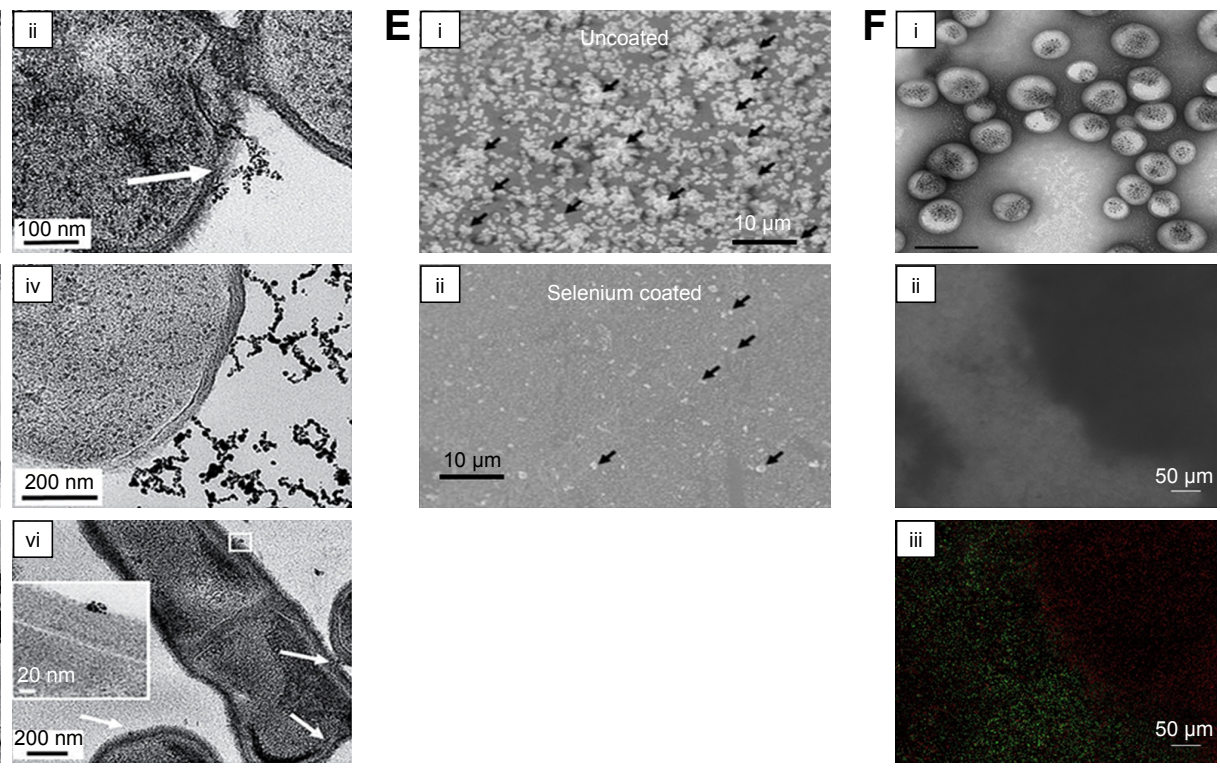

Figure 2 Antimicrobial activity of nanoparticles on bacteria.

Notes: (A) Antibacterial nanoscaffolds with silver nanoparticles. (B) (i) Simultaneous fluorescent and transmission image of E. coli culture mixed with aerogel prepared $\mathrm{MgO} /$ fluorescein (the fluorescent areas are green; the nonfluorescent areas are red). (ii and iii) AFM images. (iv and v) Cross sections and their section z-heights below. (C) Photothermal inactivation of heat-resistant bacteria on nanoporous gold disk arrays at different magnifications and array structures (i-vi). Reprinted with permission from Optical Society of America. Santos GM, de Santi Ferrara FI, Zhao G, Rodrigues DF, Shih W. Photothermal inactivation of heat-resistant bacteria on nanoporous gold disk arrays. Opt Mater Express. 2016;6(4):1217-1229.170 (D) Transmission electron micrographs of Bacillus incubated with $5 \mu \mathrm{g} \cdot \mathrm{mL}^{-1} \mathrm{mercaptopropionic}$ acid-GNP (i and ii), $5 \mu \mathrm{g} \cdot \mathrm{mL}^{-1}$ cationic 3-mercaptopropylamine-GNP (iii and iv) and $0.5 \mu \mathrm{g} \cdot \mathrm{mL}^{-1}$ cationic polyelectrolyte poly(allylamine hydrochloride)-GNP ( $v$ and vi). White arrows in figure $\mathbf{D}$ point to binding sites of NPs with cells; yellow arrows denote lysed cells or empty cells; dashed arrows show cell wall-free cytoplasmic content. (E) Novel selenium nanoparticles killing E. coli when coated on polyvinyl chloride. Arrows indicate bacteria. (F) The use of iron oxide MNPs and a magnet to penetrate an E. coli biofilm and kill bacteria (as indicated by the red dead stain; live bacteria are stained green). (i) Iron oxide nanoparticles coated in polymersomes. Scale bar=I $\mu \mathrm{m}$. (ii) Bright-field image showing the placement of a black magnet under the well plate (left) and (iii) the same area under fluorescent imaging showing red (dead) bacteria in the exact same area. Scale bar=50 $\mu$ m. (A-B) Reprinted with permission from Stoimenov PK, Klinger RL, Marchin GL, et al. Metal oxide nanoparticles as bactericidal agents. Langmuir. 2002; I8(I7):6679-6686. Copyright 2002 American Chemical Society. ${ }^{81}$ (D) Reproduced from Feng Z, Gunsolus IL, Qiu TA, et al. Impacts of gold nanoparticle charge and ligand type on surface binding and toxicity to Gramnegative and Gram-positive bacteria. Chem Sci. 20I5;6(9):5।86-5196. ${ }^{171}$

Abbreviations: E. coli, Escherichia coli; GNP, gold nanoparticle; MNP, magnetic nanoparticle.

mechanotransduction pathways. ${ }^{101}$ Numerous approaches have been used, including the introduction of shear stress by bioreactors and stiffness of patterned substrates to mechanically control cell functions. However, MNPs have proven to be superior to all these methods since they have the ability to be controlled remotely, spatially and temporally through a magnetic field..$^{54,80,102}$ On a microscopic level, the process happens as follows. First, the MNPs are coated with a 
certain targeting antibody. Once the magnetic field is applied, the cells are clustered in the direction of the magnetic field. Based on the antibody used, receptor-mediated cell function is affected. Mannix et al ${ }^{103}$ were able to achieve an increase in intracellular calcium ion levels, while Gopinath et al were able to induce the apoptotic pathway using such approaches. ${ }^{104}$ These two experiments along with many other studies have shown how the integration of MNPs can provide full details of cell functions and differentiation in regenerative medicine in a remote manner.

In another study, silver nanoparticles were used to induce cell apoptosis in BHK21 and HT29 cells. The introduction of silver nanoparticles at a concentration of $11.0 \mu \mathrm{g} \cdot \mathrm{mL}^{-1}$ triggered extracellular stresses on the membranes, resulting in an upregulation of p53 that triggered the right molecules to induce cell death. ${ }^{104}$ Figure 3 shows the silver nanoparticleand MNP-induced apoptotic pathways. Of course, in these approaches, one needs to be concerned about other cellular functions that may be inadvertently changed through nanoparticle-cell membrane attachment or internalization.

\section{Gene delivery}

Gene delivery technology targeting matured cells or stem cells has become an important issue within TE. Human mesenchymal stem cells (hMSCs) are multipotent cells that show immunosuppressive properties and have an intrinsic capacity to differentiate into various types of cells, including chondrocytes, osteoblasts, myocytes and adipocytes. ${ }^{105,106}$ For effective gene therapy applications, it is vital to build up a suitable vector system with a high gene transfection efficiency, low cytotoxicity and high specificity to unhealthy cells. Gene delivery is classified into two categories: viral and nonviral. The promise for gene delivery has been seen through the use of nanoparticles and self-assembled nanomaterials as described in the following.

\section{DNA transfection}

The advantages of nonviral methods are their simplicity and the absence of an immune response, while the disadvantage is low efficiency due to low transfection rate. ${ }^{107}$ Magnetofection is a new method for gene delivery in which gene
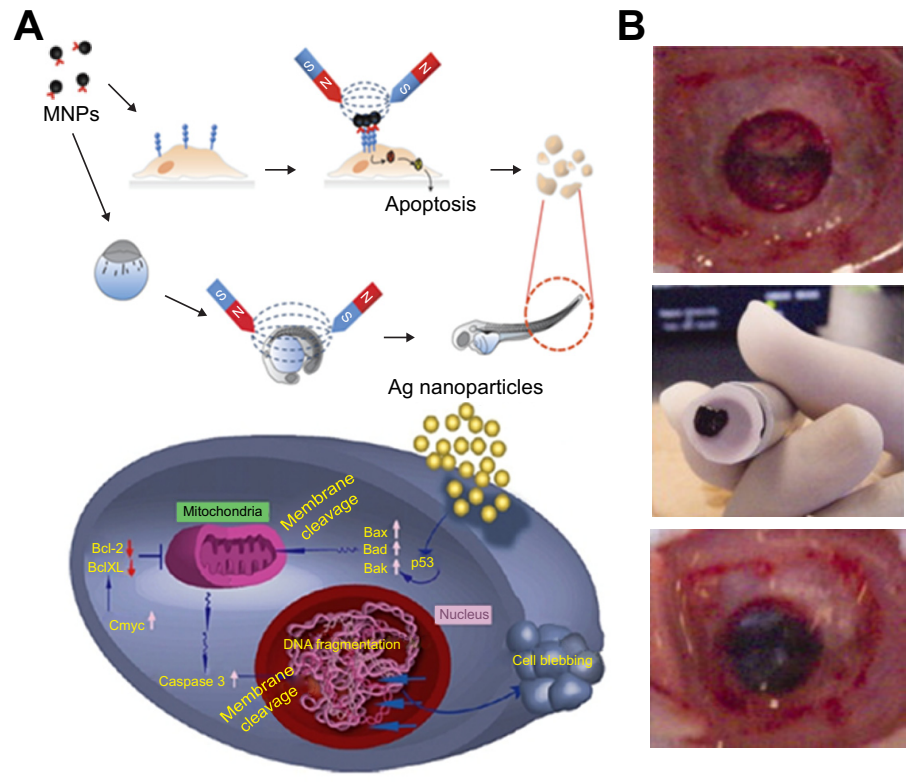

C
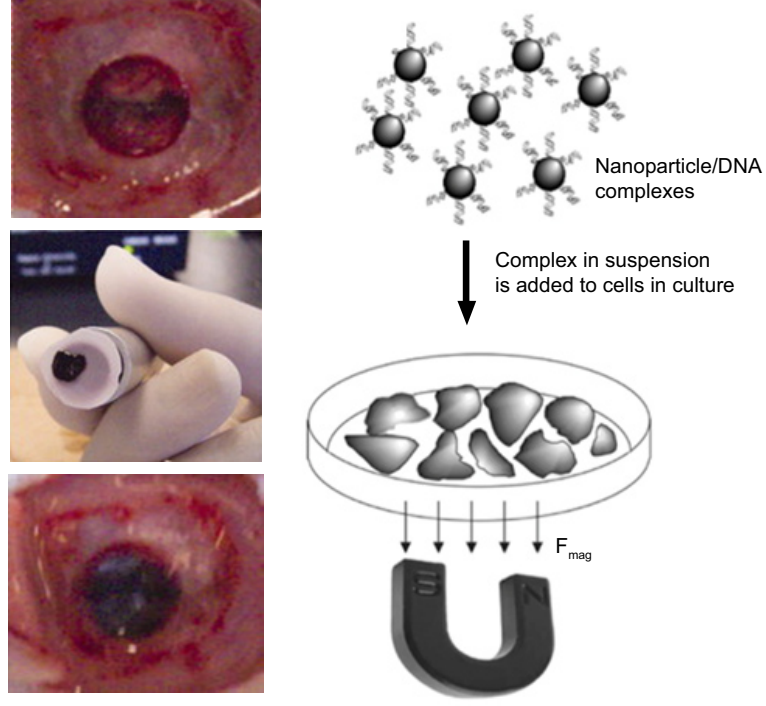

D
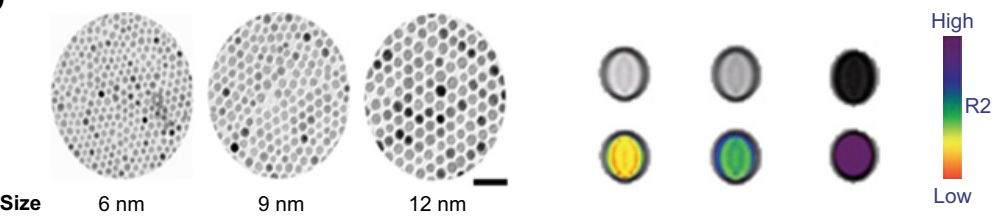

Figure 3 Utilization of magnetic particles in bioengineering applications.

Notes: (A) Upper side of the figure shows MNP-induced apoptosis, whereas the bottom side shows silver nanoparticle-induced apoptosis. (B) Transplantation procedure of MSC sheets using an electromagnet with harvesting, transportation and transplantation. (C) Principles and schematic of magnetofection. (D) Size-dependent contrast agents with their T2-weighted magnetic resonance images and color maps; the scale bar is $50 \mathrm{~nm}$. (A) Reprinted from Colloids Surf B Biointerfaces. 77(2). Gopinath P, Gogoi SK, Sanpui P, Paul A, Chattopadhyay A, Ghosh SS. Signaling gene cascade in silver nanoparticle induced apoptosis. Pages 240-245., Copyright 20I0, with permission from Elsevier. ${ }^{104}$ (B) @ 2007 Wiley Periodicals, Inc. J Biomed Mater Res Part B: Appl Biomater 2007. Reproduced from Shimizu K, Ito A, Yoshida T, Yamada Y, Ueda M, Honda H. Bone tissue engineering with human mesenchymal stem cell sheets constructed using magnetite nanoparticles and magnetic force. Journal of Biomedical Materials Research. ${ }^{172}$ (D) Reprinted from Springer Nature: Nature Medicine. Lee JH, Huh YM, Jun YW, et al. Artificially engineered magnetic nanoparticles for ultra-sensitive molecular imaging. Copyright 2007. ${ }^{173}$ Abbreviations: MNP, magnetic nanoparticle; Bcl-2, B-cell lymphoma 2; MSC, mesenchymal stem cells. 
transfection is accomplished using MNPs (Figure 3). To achieve magnetofection using plasmid DNA, cationic lipids or polymers with complexes of DNA interact with magnetic beads and then through a magnetic force are attracted onto target cells so that they can accumulate on the surface. ${ }^{108}$ There has been substantial research into various methods of magnetofection in combination with Lipofectamine, polyethyleneimine or dioleoyltrimethylammounium. ${ }^{108}$ Furthermore, in endothelial cells ${ }^{109}$ and embryonic stem cells, ${ }^{110}$ which are generally resistant to traditional transfection methods, magnetofection showed high expression levels in target cells. It was found that in fibroblasts and keratinocytes using reporter genes, the transfection efficiencies using the magnetofection technique were 36- and 10-fold higher, respectively, compared to the lipofection technique by cationic liposomes. ${ }^{111}$

Some studies have shown that iron oxide magnetic particles can attach to the gene and improve transfection efficiency. These particles were distributed within a polymer matrix or internalized in a polymer or metallic case, which binds DNA through charge contact. ${ }^{12,113}$ Another study looked at the improvement of mesoporous silica nanoparticles to uphold the uptake by the target cells. Coupled with $N-\{1-(2,3-$ dioleoyloxy)propyl $\}-N, N, N$ trimethylammonium chloride (DOTAP chloride), the structure helped to avoid aggregation and encouraged uptake. ${ }^{114} \mathrm{CNTs}$, which have shown numerous applications ${ }^{115,116}$ and can be synthesized through several different approaches, ${ }^{117,118}$ were also shown of remarkable potential as nonviral gene delivery agents. A technique called as nanotube spearing has been used to prepare nickel-embedded, magnetic nanotubes where DNA is attached. ${ }^{119}$

\section{Viral transduction}

Viral transduction methods have also been used in TE applications; however, one problem associated with this method is the difficulty in preparing viral vectors with a high titer. ${ }^{107,120}$ In one case, retroviral vectors were captured using magnetite cationic liposomes (MCLs) by adding the MCLs to a solution of retroviral vector pseudo typed through the vesicular stomatitis virus glycoprotein. ${ }^{121}$ The MCLs were then collected through the use of a magnetic force and seeded into mouse neuroblastoma cells, thereby increasing the viral titer by 55 -fold. It was noted that physical interactions due to magnetic force enhances cellular uptake of MNPs. When transduction efficiency of magnetofection with MCLs was compared with conventional methods using polybrene, the effectiveness was 6.7-fold higher for the MCLs. ${ }^{122}$

No coxsackievirus and adenovirus receptor (CAR) were expressed by using adenoviral vectors conjugated with polyethyleneimine. These vectors were coated with MNPs, which enabled transduction of a number of cell lines. Using these particles, magnetofection has been utilized to transfect a number of cell types, including epithelial cells from lungs ${ }^{123}$ and endothelial cells from blood vessels. ${ }^{109}$ These particles have also been used to effectively deliver antisense oligonucleotides $^{124}$ and siRNA to inhibit gene expression. Further development of magnetically labeled vectors with magnetic fields should provide tools for the effective treatment of different types of diseases.

\section{Magnetic cell patterning}

Successful TE requires the fabrication of tissue architecture similar to in vivo conditions. One strategy to accomplish this is to control cell adhesion within a specified design pattern. Current limitations of conventional methods include the need for extensive external equipment or requirement of usage of chemically modified surfaces. The use of MNPs for the purpose of cell patterning may serve to bypass these obstacles by offering an effective and practical alternative. Figure 4 shows the MNPs and the mediated cell patterning on an acryl resin plate. MCLs show high-cell binding capacity. A cell-patterning technique was developed using MCLs where a magnet with a magnetic field concentrator was laid under a cell culture surface. Various cell patterns were successfully fabricated using this technique by manipulating the line patterns of the magnetic field concentrators. When human umbilical vein endothelial cells were used, it was found that for the same number of cells, the cells were connected and formed capillary-like structures when patterned in a line. ${ }^{125}$ For the construction of vascular grafts, it was found that the tubular geometry did not allow for an effective delivery of the cells onto the scaffold. Another study using porcine decellularized common carotid artery showed that when a cylindrical magnet was placed into the lumen of the artery and then immersed into a suspension of NIH3T3 fibroblasts (3T3s) that had been magnetically labeled using original MCLs with a positive surface charge, almost all the 3T3s were attached to the artery compared to the very low seeding efficiency that was observed in the absence of a magnet. Reseeding the porcine decellularized common carotid artery with both smooth human muscle cells and human dermal fibroblasts successfully constructed the vascular graft using the Mag-seeding technique. ${ }^{126}$

An arginine-glycine-aspartic acid motif-containing peptide coupled to a phospholipid group on magnetite cationic liposomes (RGD-MCLs) has been shown to facilitate cell adhesion and proliferation. The RGD-MCLs were added to an ultralow-attachment plate where the culture surface was modified with a hydrophilic and neutrally charged hydrogel 
layer. Human keratinocyte $(\mathrm{HaCaT})$ cells were seeded onto the plate. Without either the RGD or MCLs, a few cells were attached to the plate. With MCLs, cells attached but low proliferation rates were noted. However, when RGD-MCLs were used, the cells adhered within a day and proliferated. Of course, one needs to be careful when using RGD since it is not an exclusive cell-binding motif and, thus, if not deactivated or fully covered by the target cells, competitor cells may attach and decrease the efficacy of the TE construct.

Another strategy investigated for cell patterning was to use MNPs coated with aminosilane and modified with poly(ethylene glycol) in combination with a magnetic force (PEG-Mags). ${ }^{122}$ The PEG-Mags were magnetically decorated onto the surface of a tissue culture dish resulting in two regions, namely, the cell-resistant PEG-Mags covering region and the native substrate surface, which was the cell adhesion region. When $\mathrm{HaCaT}$ cells were seeded, they adhered only to the native substrate surface and the PEG-Mags were washed away exposing the surface. When mouse myoblast $\mathrm{C} 2 \mathrm{C} 12$ cells were seeded into the dish, they adhered to the substrate surface creating a patterned coculture of heterotypic cells. Furthermore, almost no cytotoxic effect was observed by
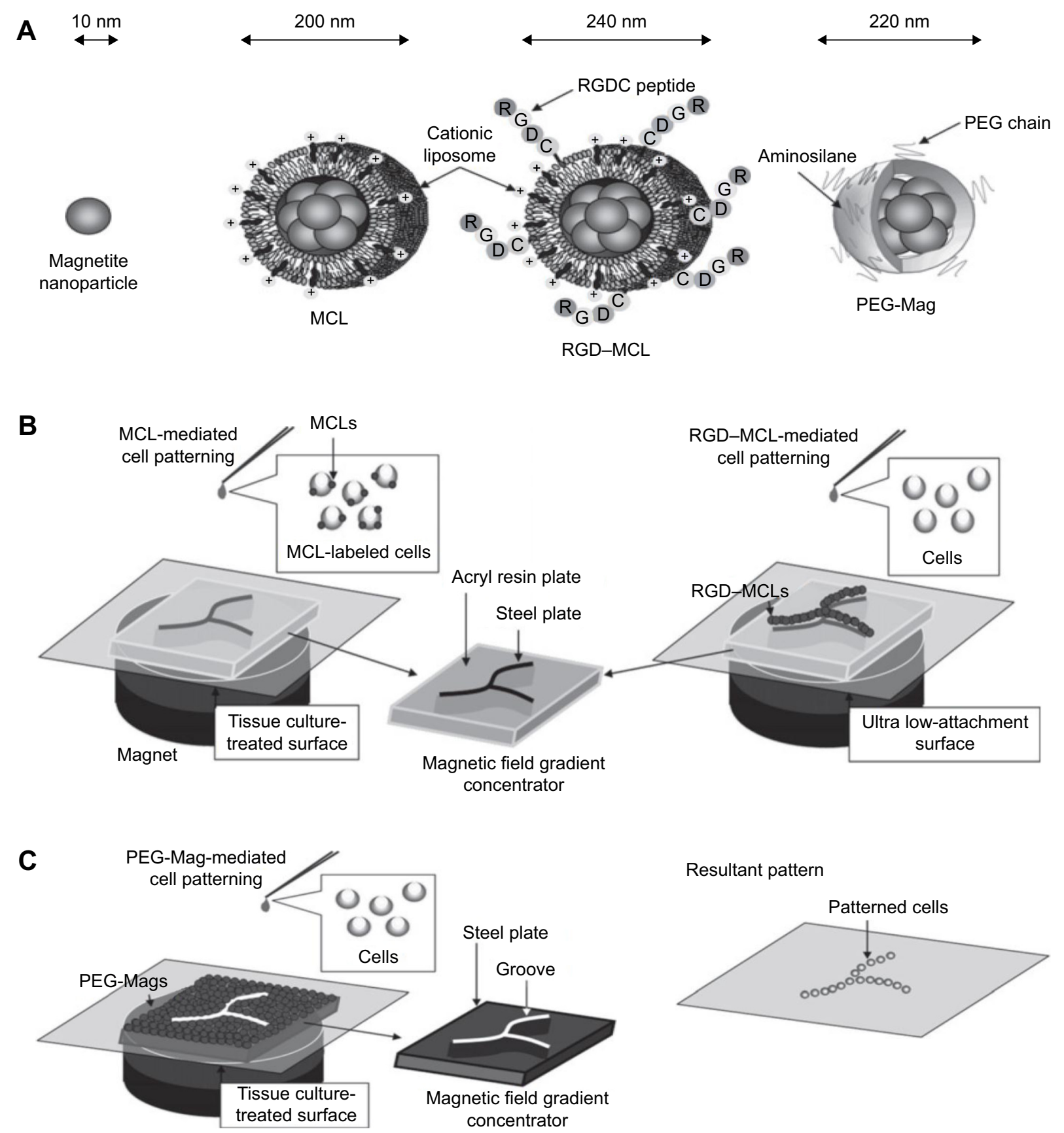

Resultant pattern

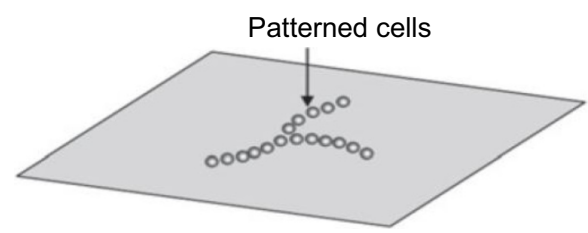

Figure 4 (Continued) 


\section{D}
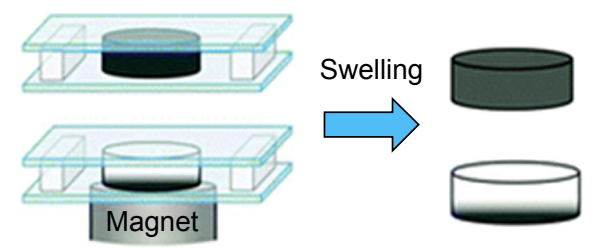

Ice crystal (pore) formation

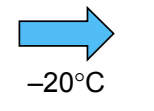

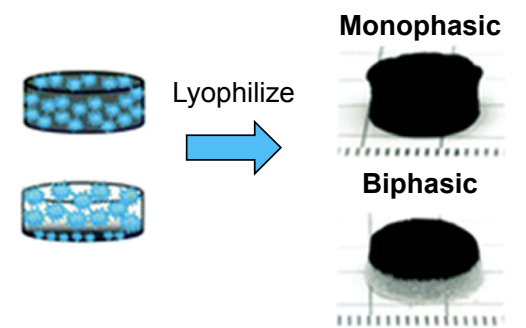

E
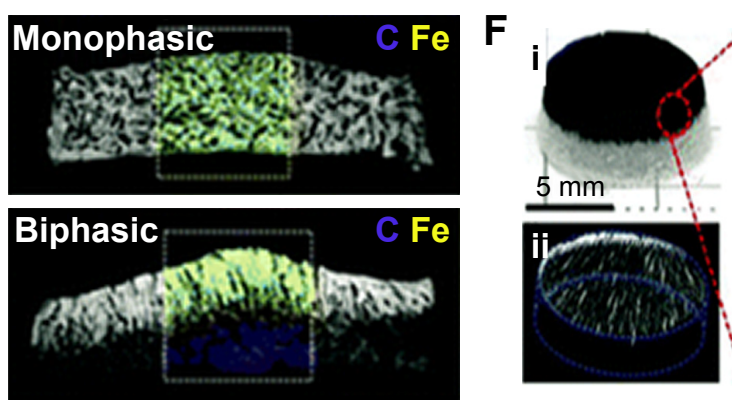

G

Field off
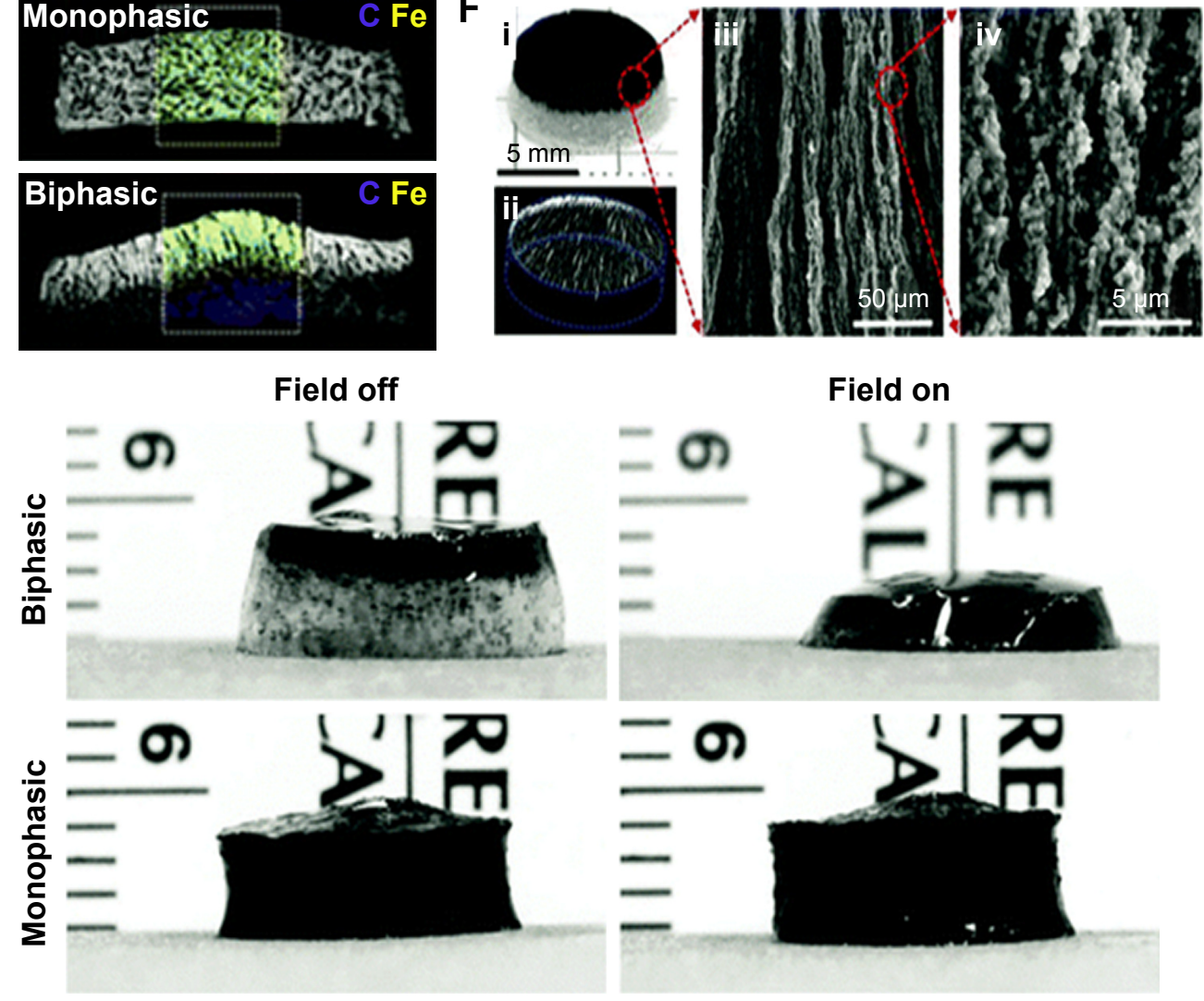

Field on

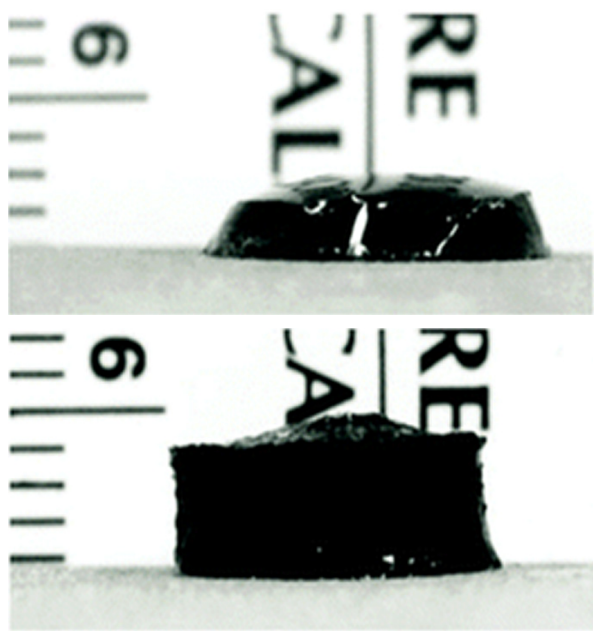

Figure 4 Magnetic cell patterning and ferrogel fabrication.

Notes: (A-C) Magnetic cell patterning using MCLs, RGD-MCLs and PEG-Mags and their resultant pattern of cells. Reprinted from Academic Press, Ito A, Kamihira M. Progress in Molecular Biology and Translational Science/Tissue Engineering Using Magnetite Nanoparticles, pages 355-395, Copyright 20II. ${ }^{174}$ (D-G) Schematic of fabrication of monophasic and biphasic ferrogels, their SEM/EDS and micro-CT images and these ferrogels in the presence of no magnetic field (field off) and a moderate vertical magnetic field gradient (field on). Reproduced from Cezar CA, Kennedy SM, Mehta M, et al. Biphasic ferrogels for triggered drug and cell delivery. Adv Healthc Mater. 20I4;3(II):I869-I876. With permission from John Wiley and Sons. ${ }^{175}$

Abbreviations: EDS, energy dispersive spectroscopy; MCL, magnetite cationic liposome; RGD-MCL, arginine-glycine-aspartic acid motif-containing peptide coupled to a phospholipid group on magnetite cationic liposomes; PEG-Mags, poly(ethylene glycol) in combination with a magnetic force; SEM, scanning electron microscopy; micro-CT, micro-computed tomography.

using PEG-Mags, signifying that this strategy of combing PEG with the MNPs provided particles with biocompatibility and low toxicity, adding to the appeal of this method. ${ }^{122}$

\section{Constructing 3D tissues}

Nanotechnology shows potential perspectives in TE. Nanoscale structures can control cellular activities such as adhesion, propagation and segregation, and most importantly, nanomaterials have unique visual and magnetic properties and thus are suitable agents for monitoring cellular performance in vivo subsequent a transplantation. Nanomaterials were subsequently developed as 3D tissue-engineered scaffolds for skin, bone, vasculature and other tissues; ${ }^{127-131}$ additionally, nanostructures have also been revealed to control the actions of primary stem cells such as adhesion, growth and differentiation. ${ }^{132-134}$ Recently, MNPs have gained lots of attention due to their exceptional magnetic properties and unique dimensions. ${ }^{135}$ MNPs are smaller in size (20-300 nm), and their magnetization directions support thermal fluctuations at room or biological temperature.

\section{Skin}

Keratinocyte sheets of five or more cellular layers were constructed, which were adequately strong for improvement and 
transplantation. A well of ultralow-attachment plated with a covalently bound hydrogel layer and a neodymium magnet under the plate was used to seed magnetically labeled keratinocytes. Without either the magnet or MCLs, the keratinocytes did not stick on to the culture surface. ${ }^{136}$ It was also observed that sheets consisted of undifferentiated keratinocytes that may be more effective in wound healing. In addition, as soon as the five-layered sheets were cultured in a medium of high calcium, they stratified to produce 10-layer epidermal sheets formed within this high-calcium medium and were substantially stronger. An added advantage of magnetic force was that the sheets labeled with MCLs floated up to the culture surface and stuck to the hydrophilic poly(vinylidene fluoride)-treated membrane placed on a cylindrical magnet, making recovery simpler.

\section{Skeletal muscle}

Magnetic force-based scaffolds of free multilayered sheets of skeletal muscle cells were constructed using mouse MCLlabeled myoblast $\mathrm{C} 2 \mathrm{C} 12$ cells seeded in ultra-low attachment plates with a magnet below the plates. The cells accumulated uniformly forming dense, strong and multilayered sheets. On the other hand, when the magnet was removed, the cells formed small aggregates instead. ${ }^{137}$ The method was then adjusted to fabricate string-shaped 3D tissues similar to skeletal muscle fiber bundles. The magnetic field gradient forced the cells to aggregate in string-like lines, and by controlling the magnetic field gradient, the width and thickness could be manipulated. ${ }^{137}$ To date, a number of new strategies have been established for the manufacturing of skeletal muscle tissues. Saxena et $\mathrm{al}^{138}$ presented vascularized skeletal muscle constructs where myoblasts were immobilized on artificial biodegradable polymers. Another group showed a 3D fabrication with scaffold-free self-assembly of myoblast cells on a silicone surface. ${ }^{139}$ Moon du et al ${ }^{140}$ developed skeletal muscle tissue constructs using collagen-based acellular tissue scaffolds with improved contractile force generation. Akiyama et $\mathrm{al}^{141}$ and Sato et $\mathrm{al}^{142}$ developed a TE technique called magnetic force-based tissue engineering (Mag-TE) where a magnetic force was applied and cells labeled with MNPs were used to engineer tissue constructs. Using Mag-TE, they also showed that the B-cell lymphoma 2 (Bcl-2) protein improved the development of synthetic skeletal muscle tissue constructs with an elevated cell density. ${ }^{141,142}$

\section{Liver}

Recent research has shown that Mag-TE can be used as a cell sheet for engineering of liver tissue. An example can be seen
A

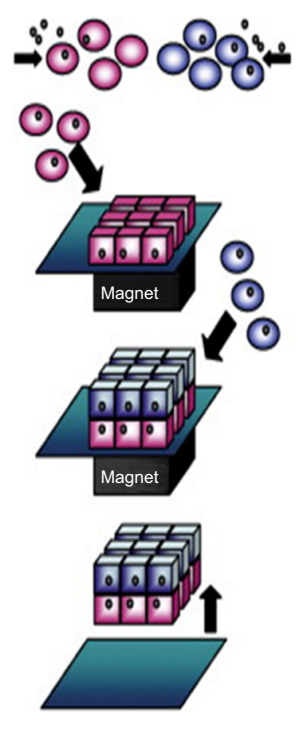

B

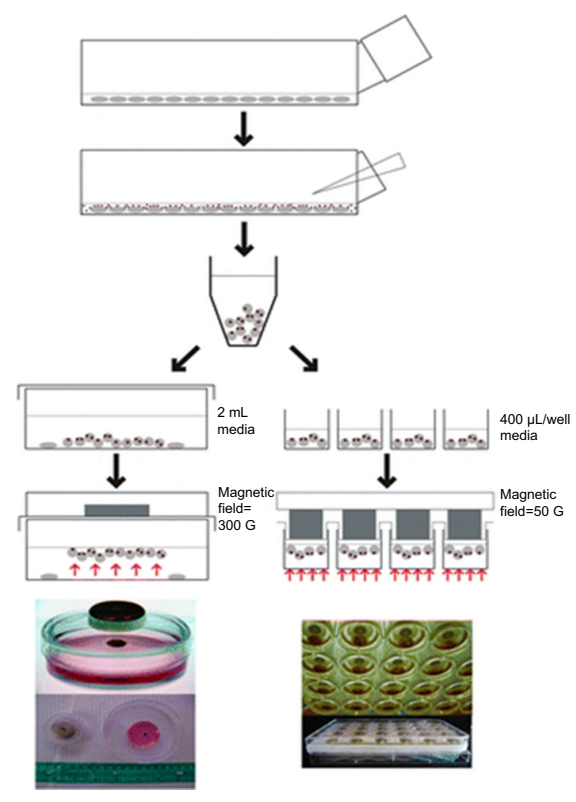

C

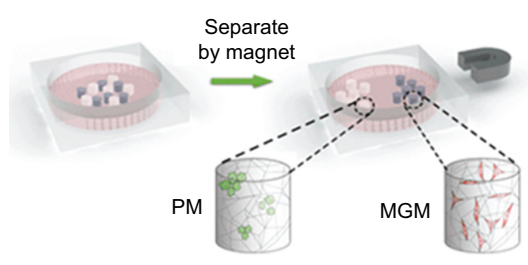

D

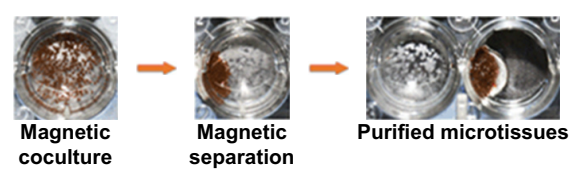

E
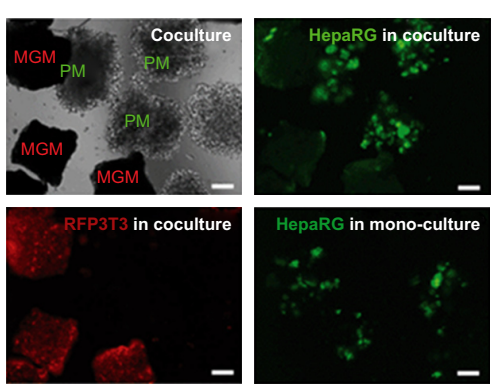

Figure 5 Magnetic culturing of cells using cell levitation and cocultures.

Notes: (A) Schematic of heterotypic cell cocultures using magnetic force. (B) Schematic of magnetic levitation in a Petri dish (left) and a 24-well plate (right). The cells are levitated to the air-liquid interface by placing a neodymium magnet above the dish or well. Cell culture under magnetic stimuli: (C) schematic drawing of the setup, (D) brightfield image and (E) fluorescence images of the two types of microcryogels (poly(ethyelene glycol) diacryate microcryogels [PM]; and magnetic gelatin microcryogels [MGM]) mixed together and co-cultured in the system. Scale bar is $200 \mu \mathrm{m}$. (A) Reprinted from Trends Biotechnol. 27(8). Corchero JL, Villaverde A. Biomedical applications of distally controlled magnetic nanoparticles. Pages 468-476. Copyright 2009, with permission from Elsevier. ${ }^{176}$ (B) The publisher for this copyrighted material is Mary Ann Liebert, Inc. publishers. Tseng H, Gage JA, Raphael RM, et al. Assembly of a three-dimensional multitype bronchiole coculture model using magnetic levitation. Tissue Eng Part C Methods. 2013;19(9):665-675. ${ }^{177}$ (C-E) Republished with permission of Royal Society of Chemistry, from Magnetically controllable 3D microtissues based on magnetic microcryogels, Liu W, Li Y, Feng S, et al, Volume I4(I5), 20I4; permission conveyed through Copyright Clearance Center, Inc. ${ }^{178}$ 
in Figure 5 in magnetic cell patterning and Ferro gel fabrication. In case of the liver, it was found that the magnetic force allowed for close and tight cell interactions, which may have caused the deposition of an ECM and cytokines between cell layers, enhancing liver function. Hepatocytes and endothelial cells were cocultured using Mag-TE. Human aortic endothelial cells (HAECs) were labeled using MCLs and placed onto a layer of rat hepatocytes. Multilayers of HAECs were formed where magnets were placed and remained attached to the hepatocyte layer in an even manner. The layered cocultures also managed to maintain an increased amount of albumin secretion for a period of at least 8 days. ${ }^{143}$ Another study looked at magnetically labeled HepG2 (hepatocyte model) and NIH3T3 (stromal fibroblast model) cells. The cells were seeded in wells of an ultra-low attachment plated with a magnet underneath. The cells were attracted to the magnet at the bottom and formed strong sheet-like structures. When the magnet was removed, the cell sheets detached and were disengaged without disruption with the use of a magnet. ${ }^{144}$

\section{Nanoparticles in biomolecular detection}

The application of biomolecular detection and biosensors is rapidly gathering pace in the field of TE. ${ }^{145}$ Biosensors are biological devices that recognize a change in molecules through physiochemical detection (Figure 6). In TE, various types of biosensors have been used, such as electrochemical, optical, magnetic and acoustic, for the detection of functional protein molecules, glucose and pathogenic microbes. ${ }^{146}$ Most importantly, however, is the rise in the application of nanoparticles in biomolecular detection. Nanoparticles in biosensors have been used for DNA, nucleic acid and protein detection, among other applications, due to their high reactivity and their advantageous chemical properties. ${ }^{147,148}$ The rising prominence of nanoparticle applications in biomolecular sensors and the importance of biosensors in TE highlight the potential of nanoparticles in TE. Hopefully in the near future, researchers can incorporate intelligent nanoscale biosensors inside scaffolds, cell sheets or associated locations to track the development of engineered tissues after transplantation and grafting. We also believe that incorporating nanomaterials in 3D-engineered tissues could serve to reduce inflammatory responses to transplanted engineered tissues by modulating immune cell adhesion and cell viability.

\section{Optical detection}

One of the prime examples of the use of nanoparticles as biosensors is through optical sensors and optical imaging in
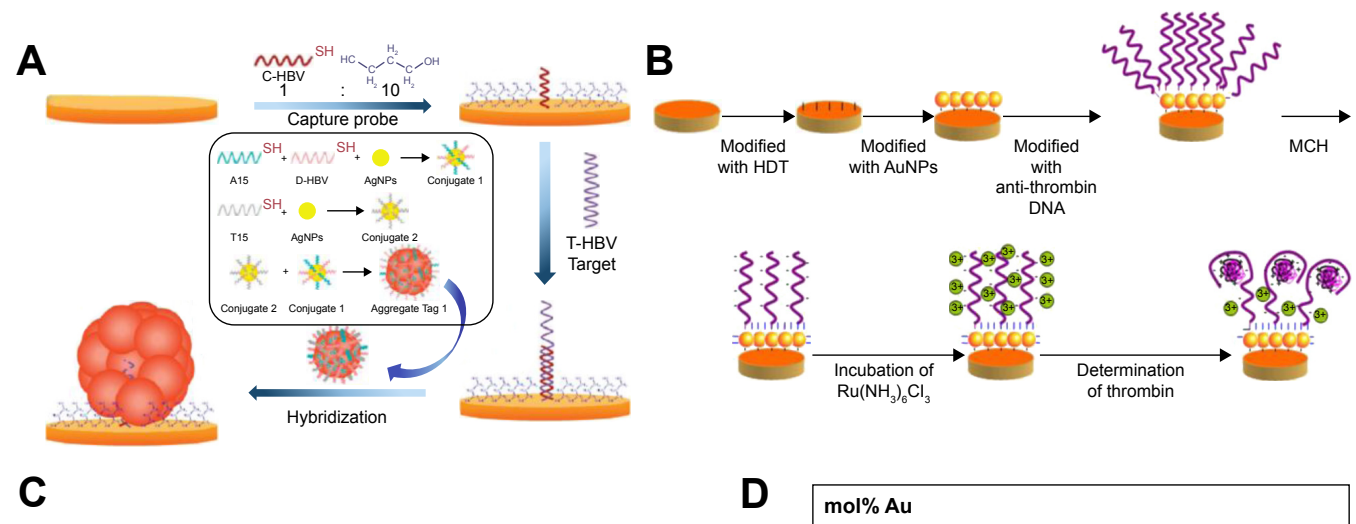

C

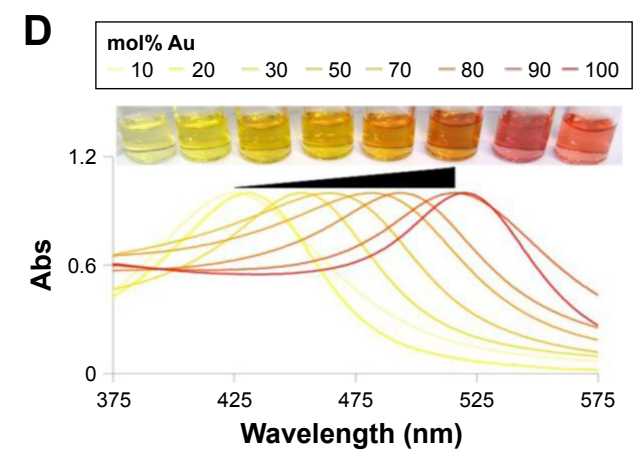

Figure 6 Biosensing principles using nanoparticles and nanomaterials.

Notes: (A) Electromechanical biodetection schematic for silver nanoparticles. (B) Quantum dot electromechanical detection of DNA strands. (C) Electrochemical detection schematic for silver nanoparticles. (D) Example of localized surface plasmon resonance modulation by altering nanoparticle compositions. (A) Reprinted by permission from Springer Nature: Anal Bioanal Chem. Aptamer-based electrochemical approach to the detection of thrombin by modification of gold nanoparticles. Li L, Zhao H, Chen Z, Mu X, Guo L. Copyright 2010. ${ }^{179}$ (B) Reprinted with permission from Wang J, Liu G, Merkoçi A. Electrochemical coding technology for simultaneous detection of multiple DNA targets. J Am Chem Soc. 2003; I25(II):32I4-3215. Copyright 2003 American Chemical Society. ${ }^{180}$ (C) Reprinted with permission from Li H, Sun Z, Zhong W, Hao N, Xu D, Chen HY. Ultrasensitive electrochemical detection for DNA arrays based on silver nanoparticle aggregates. Anal Chem. 20I0;82(I3):5477-5483. Copyright 20I0 American Chemical Society. ${ }^{165}$ (D) Reprinted with permission from Doria G, Conde J, Veigas B, et al. Noble metal nanoparticles for biosensing applications. Sensors (Basel). 2012;12(2):1657-1687. ${ }^{181}$

Abbreviation: Abs, absolute. 
which semiconductors (ie, quantum dots) as well as GNPs and silica nanoparticles have been used. ${ }^{148}$ Quantum dots have been used due to their high stability, brightness and lasting luminescence. ${ }^{149}$ Goldman et a ${ }^{150}$ used luminescent quantum dots for protein detection in immunoassays. ${ }^{149}$ Quantum dots were also used for DNA sensing in a study conducted by Sharon et al. ${ }^{151}$ In this study, the hemin structure in CdSe and $\mathrm{ZnS}$ quantum dots was used in order to develop new optical sensing techniques. Owing to the risk of toxicity during in vivo applications associated with heavy quantum dots, ${ }^{152}$ carbon quantum dots have been developed by Ding et al. ${ }^{153}$ These quantum dots have been found to have low cytotoxicity and have been used for molecule detection. Metal nanoparticles, on the other hand, are used in optical detection due to their tunable strength, bandwidth and frequency. These characteristics, attributed to the collective oscillation mode, make metal nanoparticles perfect for optical applications. ${ }^{154}$ Newman et al ${ }^{155}$ developed optical sensors based on GNPs. In their study, the GNPs with silica microparticles were used to detect organophosphate molecules.

\section{Electrical detection}

Nanoparticles have also been used as electrical detectors for DNA molecules through electric signals. With nanoparticles acting as intermediaries, the action of the DNA is converted to electrical signals. ${ }^{156}$ Park et al ${ }^{157}$ developed an electrical DNA detection method through binding of oligonucleotides with GNPs with a high accuracy. GNPs have also been implemented by Noor et al ${ }^{158}$ for DNA detection. In their study, DNA was mounted on a silicon chip between gold nanoelectrodes. The GNPs were found to increase conductivity between the electrodes, thus enhancing the process of DNA detection. MNPs and CNTs have also been used for electrical detection. One example is an experiment ${ }^{159}$ that was conducted by encapsulating MNP in CNTs. The results showed enhanced electrical and magnetic properties.

\section{Electrochemical detection}

Electrochemical sensors utilize the selective detection of biological elements with the sensitivity of electrical sensors for element recognition. The sensors chemically react with the analyte to produce an electrical signal. ${ }^{160}$ Nanoparticles have been used as electrochemical biosensors due to the greater surface area they offer, along with their greater chemical convenience and superior electrical conductivity. ${ }^{161}$ Wang et $\mathrm{al}^{162}$ used GNPs to enhance the immobilization of an antigen. The study showed that the use of GNPs also improved antigen and antibody detection. GNPs have also been used as electrochemical sensors for DNA detection. One example is a study conducted by Li et al. ${ }^{163}$ Apart from GNPs, various types of nanoparticles have been used in electrochemical sensors. One example is a study conducted by Cui et al $^{164}$ in which CdTe nanoparticles were used in order to develop a two-fold immunosensor as an electrochemical sensor and fluorescent label. GNPs were also used to swathe the chip upon which the sensor was constructed. Another study was conducted by Li et al $^{165}$ in which oligonucleotidefunctionalized silver nanoparticles were developed for DNA detection. Silver nanoparticles were shown to have excellent properties that are yet to be properly utilized.

Another example of electrochemical detection is a sensor that was developed for an orthopedic hip implant. This titanium-based implant was first anodized to possess nanotubes from which CNTs were grown using chemical vapor deposition. ${ }^{166}$ The CNTs could then measure the resistance of the cells that attach to the implant, send such information via $\mathrm{RF}$ to a hand-held device and even be remotely activated to release bone growth factors, anti-inflammatory agents or antibiotics to the site of the need to ensure implant success. Such electrochemical detection of biological events may be the future of nanomaterial use in medical devices as they can sense in real time biological events depending on the individual's response to the implant to promote success, perhaps the true definition of personalized medicine.

\section{Challenges and future perspectives}

While nanoparticles have demonstrated promising potential in TE applications such as enhancement of biological, mechanical and electrical properties; antimicrobial effects; gene delivery and construction of engineered tissues, many challenges still lie ahead to introduce them into widespread clinical applications. For example, a compelling need exists, at first, for better assessment tools and methods of nanoparticle toxicity, carcinogenicity and teratogenicity. Second, the toxicity, carcinogenicity and teratogenicity of nanoparticles are all highly dose-dependent and exposure-dependent. In many applications, the nanoparticles are used below their threshold concentrations at which they are considered not harmful. However, bioaccumulation of nanoparticles inside the body over a large period of time is well known. Thus, any nanoparticle used in the human body has the potential to accumulate over a long period of time to reach a concentration that can cause toxicity to cells, cancers or harmful effects on reproductive systems and fetuses before their birth. In addition, even though there are numerous products containing nanoparticles/nanomaterials already in the market, 
there are still some scientific and methodological gaps in the knowledge on specific hazards of nanomaterials. Currently, to the best of our knowledge, there are no international standards yet for nano-specific risk assessments, including specific data requirements and testing strategies. The risk assessments of nanomaterials are laborious and costly. Currently, manufacturers are committed to assess the safety of their nanoparticle-based products and to implement the necessary safety measures (self-supervision). To date, the regulatory tools are not nano-specific; eg, the data requirements for notification of chemicals, criteria for classification and labeling requirements for safety data sheets are still not widely available. Thus, there is a need for precautionary measures for applications of nanoparticles wherever there is a possibility of chronic bioaccumulation.

\section{Conclusion}

Nanoparticles exhibit superior biocompatibility and wellestablished strategies for surface modification, which have made them highly effective in numerous biomedical applications. The electric coupling between decellularized cells and proliferation rates upon several tissues have also been enhanced using nanoparticles. The validity of nanoparticles, when it comes to antibacterial growth, has also been studied with much promise. These nanoparticles have been deposited on biocomposite scaffolds, thus regulating bacterial infection during reconstructive bone surgery. Induction of cell mechanotransduction, which is responsible for many physiological processes in the body, was also stimulated by remotely controlled nanoparticles. This review has mentioned a new method for gene delivery. Specifically, magnetofection, which was accomplished through the use of plasmid DNA cationic lipids with complexes of DNA as they interacted through a magnetic force, thus increasing transfection efficiency. Related to this is the use of nanoparticles for the purpose of cell patterning. Three strategies were investigated for cell patterning: the use of MCLs, RGD motif-containing peptide coupled to the phospholipid of magnetite cationic liposomes and aminosilane modified with PEG and magnetic force (PEG-Mags).

The numerous existing applications in the literature reiterate the great potential nanoparticles can have on TE through biosensors. Nanoparticles have been shown to develop optical, electrical and electrochemical biosensors for molecules, proteins and DNA detection with highly accurate results. By optimizing these functions, these sensors could have a great influence on medical use. Although nanoparticles show a promising future in TE applications, there is still a lack of in vivo experimentation that needs to be done in order to verify the wide variety of successful results from in vitro studies.

We believe that in the near future, we could visualize the use of smart nanoparticles that can engage and direct stem cells to preferred sites in the body and dictate the formation of tissues in vivo.

\section{Acknowledgments}

This article was supported by the GCC research program (No GCC-2017-005), Qatar University, Qatar, and by NPRP grant (NPRP 9-144-03-021) from QNRF (Qatar National Research Funding), a part of Qatar Foundation. The Statements made herein are solely the responsibility of the authors. Shabir H acknowledges funding from Swiss National Science Foundation.

\section{Disclosure}

The authors report no conflicts of interest in this work.

\section{References}

1. Hasan A, Memic A, Annabi N, et al. Electrospun scaffolds for tissue engineering of vascular grafts. Acta Biomater. 2014;10(1):11-25.

2. Hasan A, Paul A, Memic A, Khademhosseini A. A multilayered microfluidic blood vessel-like structure. Biomed Microdevices. 2015;17(5):88.

3. Paul A, Manoharan V, Krafft D, et al. Nanoengineered biomimetic hydrogels for guiding human stem cell osteogenesis in three dimensional microenvironments. J Mater Chem B. 2016;4(20):521-528.

4. Hasan A, Paul A, Vrana NE, et al. Microfluidic techniques for development of 3D vascularized tissue. Biomaterials. 2014;35(26):7308-7325.

5. Hasan A, Ragaert K, Swieszkowski W, et al. Biomechanical properties of native and tissue engineered heart valve constructs. $J$ Biomech. 2014;47(9):1949-1963.

6. Kestell AE, DeLorey GT. Nanoparticles: Properties, Classification, Characterization, and Fabrication. Hauppauge, NY: Nova Science Publishers, Inc; 2009.

7. Wilson DS, Dalmasso G, Wang L, Sitaraman SV, Merlin D, Murthy N. Orally delivered thioketal nanoparticles loaded with TNF-alpha-siRNA target inflammation and inhibit gene expression in the intestines. Nat Mater. 2010;9(11):923-928.

8. Shi J, Votruba AR, Farokhzad OC, Langer R. Nanotechnology in drug delivery and tissue engineering: from discovery to applications. Nano Lett. 2010;10(9):3223-3230.

9. Mironov V, Kasyanov V, Markwald RR. Nanotechnology in vascular tissue engineering: from nanoscaffolding towards rapid vessel biofabrication. Trends Biotechnol. 2008;26(6):338-344.

10. Koo OM, Rubinstein I, Onyuksel H. Role of nanotechnology in targeted drug delivery and imaging: a concise review. Nanomedicine. 2005; 1(3): 193-212.

11. Furno F, Morley KS, Wong B, et al. Silver nanoparticles and polymeric medical devices: a new approach to prevention of infection? J Antimicrob Chemother. 2004;54(6):1019-1024.

12. Prasad GL. Biomedical applications of nanoparticles. In: Webster TJ, editor. Safety of Nanoparticles. New York: Springer; 2009:89-109.

13. Basarkar A, Singh J. Poly (lactide-co-glycolide)-polymethacrylate nanoparticles for intramuscular delivery of plasmid encoding interleukin-10 to prevent autoimmune diabetes in mice. Pharm Res. 2009;26(1):72-81.

14. Wang X, Yang L, Chen ZG, Shin DM. Application of nanotechnology in cancer therapy and imaging. CA Cancer J Clin. 2008;58(2):97-110.

15. Panyam J, Labhasetwar V. Biodegradable nanoparticles for drug and gene delivery to cells and tissue. Adv Drug Deliv Rev. 2003;55(3):329-347. 
16. Brigger I, Dubernet C, Couvreur P. Nanoparticles in cancer therapy and diagnosis. Adv Drug Deliv Rev. 2002;54(5):631-651.

17. Kataoka K, Harada A, Nagasaki Y. Block copolymer micelles for drug delivery: design, characterization and biological significance. Adv Drug Deliv Rev. 2001;47(1):113-131.

18. Hansma HG. Surface biology of DNA by atomic force microscopy. Annu Rev Phys Chem. 2001;52:71-92.

19. Roy K, Mao HQ, Huang SK, Leong KW. Oral gene delivery with chitosan-DNA nanoparticles generates immunologic protection in a murine model of peanut allergy. Nat Med. 1999;5(4):387-391.

20. Sensenig R, Sapir Y, MacDonald C, Cohen S, Polyak B. Magnetic nanoparticle-based approaches to locally target therapy and enhance tissue regeneration in vivo. Nanomedicine (Lond). 2012;7(9):1425-1442.

21. Lux F, Zeisler R. Investigations of the corrosive deposition of components of metal implants and of the behaviour of biological trace elements in metallosis tissue by means of instrumental multi-element activation analysis. J Radioanal Nucl Chem. 1974;19(2):289-297.

22. Schnabel C, Herpers U, Michel R, Löer F, Buchhorn G, Willert H-G. Changes of concentrations of the elements $\mathrm{Co}, \mathrm{Cr}, \mathrm{Sb}$, and $\mathrm{Sc}$ in tissues of persons with joint implants. In: Kučera J, Obrusník I, Sabbioni E (editors). Nuclear Analytical Methods in the Life Sciences 1994. Springer; 1994:389-395.

23. Agins H, Alcock NW, Bansal M, et al. Metallic wear in failed titaniumalloy total hip replacements. J Bone Joint Surg. 1988;70(3):347-356.

24. Rodríguez de la Flor M, Hernández-Vaquero D, Fernández-Carreira JM. Metal presence in hair after metal-on-metal resurfacing arthroplasty. J Orthop Res. 2013;31(12):2025-2031.

25. Radomska A, Leszczyszyn J, Radomski MW. The nanopharmacology and nanotoxicology of nanomaterials: new opportunities and challenges. Adv Clin Exp Med. 2016;25(1):151-162.

26. Khang D, Kim SY, Liu-Snyder P, Palmore GT, Durbin SM, Webster TJ. Enhanced fibronectin adsorption on carbon nanotube/poly(carbonate) urethane: independent role of surface nano-roughness and associated surface energy. Biomaterials. 2007;28(32):4756-4768.

27. Mostofizadeh A, Li Y, Song B, Huang Y. Synthesis, properties, and applications of low-dimensional carbon-related nanomaterials. J Nanomater. 2011;2011:16.

28. Khan I, Saeed K, Khan I. Nanoparticles: properties, applications and toxicities. Arabian J Chem. In Press 2017.

29. Ali A, Zafar H, Zia M, et al. Synthesis, characterization, applications, and challenges of iron oxide nanoparticles. Nanotechnol Sci Appl. 2016;9:49.

30. Gawande MB, Goswami A, Felpin FX, et al. Cu and Cu-based nanoparticles: synthesis and applications in catalysis. Chem Rev. 2016;116(6): 3722-3811.

31. Liu C-J, Burghaus U, Besenbacher F, Wang ZL. Preparation and characterization of nanomaterials for sustainable energy production. ACS Nano. 2010;4(10):5517-5526.

32. Memic A, Alhadrami HA, Hussain MA, et al. Hydrogels 2.0: improved properties with nanomaterial composites for biomedical applications. Biomed Mater. 2015;11(1):014104.

33. Giljohann DA, Seferos DS, Daniel WL, Massich MD, Patel PC, Mirkin CA. Gold nanoparticles for biology and medicine. Angew Chem Int Ed Engl. 2010;49(19):3280-3294.

34. Dykman L, Khlebtsov N. Gold nanoparticles in biomedical applications: recent advances and perspectives. Chem Soc Rev. 2012;41(6):2256-2282.

35. Boisselier E, Astruc D. Gold nanoparticles in nanomedicine: preparations, imaging, diagnostics, therapies and toxicity. Chem Soc Rev. 2009; 38(6):1759-1782.

36. Chen Y, Li N, Yang Y, Liu Y. A dual targeting cyclodextrin/gold nanoparticle conjugate as a scaffold for solubilization and delivery of paclitaxel. RSC Adv. 2015;5(12):8938-8941.

37. Ko WK, Heo DN, Moon HJ, et al. The effect of gold nanoparticle size on osteogenic differentiation of adipose-derived stem cells. J Colloid Interface Sci. 2015;438:68-76.

38. Suh KS, Lee YS, Seo SH, Kim YS, Choi EM. Gold nanoparticles attenuates antimycin A-induced mitochondrial dysfunction in MC3T3-E1 osteoblastic cells. Biol Trace Elem Res. 2013;153(1-3):428-436.
39. Liu D, Zhang JC, Yi CQ, Yang MS. The effects of gold nanoparticles on the proliferation, differentiation, and mineralization function of MC3T3-E1 cells in vitro. Chin Sci Bull. 2010;55(11):1013-1019.

40. Bessa PC, Casal M, Reis RL. Bone morphogenetic proteins in tissue engineering: the road from laboratory to clinic, part II (BMP delivery). J Tissue Eng Regen Med. 2008;2(2-3):81-96.

41. Lim JS, Kook MS, Jung S, et al. Plasma treated high-density polyethylene (HDPE) medpor implant immobilized with rhBMP-2 for improving the bone regeneration. J Nanomater. 2014;2014:7.

42. Benglis D, Wang MY, Levi AD. A comprehensive review of the safety profile of bone morphogenetic protein in spine surgery. Neurosurgery. 2008;62(5 suppl 2):ONS423-ONS431; discussion ONS431.

43. Lin Z, Fateh A, Salem DM, Intini G. Periosteum: biology and applications in craniofacial bone regeneration. J Dent Res. 2014;93(2):109-116.

44. Heo DN, Ko WK, Bae MS, et al. Enhanced bone regeneration with a gold nanoparticle-hydrogel complex. JMater Chem B. 2014;2(11):1584-1593.

45. Subbiah R, Veerapandian M, Yun KS. Nanoparticles: functionalization and multifunctional applications in biomedical sciences. Curr Med Chem. 2010;17(36):4559-4577.

46. Jaconi M. Nanomedicine: gold nanowires to mend a heart. Nat Nanotechnol. 2011;6(11):692-693.

47. Ravichandran R, Sridhar R, Venugopal JR, Sundarrajan S, Mukherjee S, Ramakrishna S. Gold nanoparticle loaded hybrid nanofibers for cardiogenic differentiation of stem cells for infarcted myocardium regeneration. Macromol Biosci. 2014;14(4):515-525.

48. Jawad H, Lyon AR, Harding SE, Ali NN, Boccaccini AR. Myocardial tissue engineering. Br Med Bull. 2008;87:31-47.

49. Liu H, Slamovich EB, Webster TJ. Less harmful acidic degradation of poly(lactic-co-glycolic acid) bone tissue engineering scaffolds through titania nanoparticle addition. Int J Nanomed. 2006;1(4):541-545.

50. Wanjale SD, Jog JP. Crystallization and phase transformation kinetics of poly (1-butene)/MWCNT nanocomposites. Polymer. 2006;47(18): 6414-6421.

51. El Fray M, Boccaccini AR. Novel hybrid PET/DFA-TiO nanocomposites by in situ polycondensation. Mater Lett. 2005;59(18):2300-2304.

52. Liu A, Hong Z, Zhuang X, et al. Surface modification of bioactive glass nanoparticles and the mechanical and biological properties of poly (L-lactide) composites. Acta Biomater. 2008;4(4):1005-1015.

53. Jawad H, Boccaccini AR, Ali NN, Harding SE. Assessment of cellular toxicity of $\mathrm{TiO}_{2}$ nanoparticles for cardiac tissue engineering applications. Nanotoxicology. 2011;5(3):372-380.

54. Lim D, Lee E, Kim H, Park S, Baek S, Yoon J. Multi stimuli-responsive hydrogel microfibers containing magnetite nanoparticles prepared using microcapillary devices. Soft Matter. 2015;11(8):1606-1613.

55. Wang Q, Chen D. Synthesis and characterization of a chitosan based nanocomposite injectable hydrogel. Carbohydr Polym. 2016;136: 1228-1237.

56. Kubota Y, Shuin T, Kawasaki C, et al. Photokilling of T-24 human bladder cancer cells with titanium dioxide. Br J Cancer. 1994;70(6): $1107-1111$

57. Li N, Fan X, Tang K, Zheng X, Liu J, Wang B. Nanocomposite scaffold with enhanced stability by hydrogen bonds between collagen, polyvinyl pyrrolidone and titanium dioxide. Colloids Surf B Biointerfaces. 2016;140:287-296.

58. Luderer F, Begerow I, Schmidt W, et al. Enhanced visualization of biodegradable polymeric vascular scaffolds by incorporation of gold, silver and magnetite nanoparticles. J Biomater Appl. 2013;28(2):219-231.

59. Kim H, Che L, Ha Y, Ryu W. Mechanically-reinforced electrospun composite silk fibroin nanofibers containing hydroxyapatite nanoparticles. Mater Sci Eng C. 2014;40:324-335.

60. Gonçalves EM, Oliveira FJ, Silva RF, et al. Three-dimensional printed PCL-hydroxyapatite scaffolds filled with CNTs for bone cell growth stimulation. J Biomed Mater Res B Appl Biomater. 2016;104(6):1210-1219.

61. Ju YM, Yu B, Koob TJ, et al. A novel porous collagen scaffold around an implantable biosensor for improving biocompatibility. I. In vitro/ in vivo stability of the scaffold and in vitro sensitivity of the glucose sensor with scaffold. J Biomed Mater Res A. 2008;87(1):136-146. 
62. Han ZJ, Rider AE, Ishaq M, et al. Carbon nanostructures for hard tissue engineering. RSC Adv. 2013;3(28):11058-11072.

63. Magiera A, Markowski J, Menaszek E, et al. PLA-based hybrid and composite electrospun fibrous scaffolds as potential materials for tissue engineering. J Nanomater. 2017;2017:11.

64. Pan L, Pei X, He R, Wan Q, Wang J. Multiwall carbon nanotubes/ polycaprolactone composites for bone tissue engineering application. Colloids Surf B Biointerfaces. 2012;93:226-234.

65. Rodríguez-Lozano FJ, García-Bernal D, Aznar-Cervantes S, et al. Potential of graphene for tissue engineering applications. Transl Res. 2015;166(4):399-400.

66. Feng L, Liu Z. Graphene in biomedicine: opportunities and challenges. Nanomedicine. 2011;6(2):317-324.

67. Kim J, Kim YR, Kim YJ, et al. Graphene-incorporated chitosan substrata for adhesion and differentiation of human mesenchymal stem cells. J Mater Chem B. 2013;1(7):933-938.

68. Chen GY, Pang DW, Hwang SM, Tuan HY, Hu YC. A graphene-based platform for induced pluripotent stem cells culture and differentiation. Biomaterials. 2012;33(2):418-427.

69. Ain QU, Khan AN, Nabavinia M, Mujahid M. Enhanced mechanical properties and biocompatibility of novel hydroxyapatite/TOPAS hybrid composite for bone tissue engineering applications. Mater Sci Eng C. 2017;75:807-815.

70. Mirahmadi F, Tafazzoli-Shadpour M, Shokrgozar MA, Bonakdar S. Enhanced mechanical properties of thermosensitive chitosan hydrogel by silk fibers for cartilage tissue engineering. Mater Sci Eng C. 2013; 33(8):4786-4794.

71. Sambudi NS, Sathyamurthy M, Lee GM, et al. Electrospun chitosan/ poly (vinyl alcohol) reinforced with $\mathrm{CaCO}_{3}$ nanoparticles with enhanced mechanical properties and biocompatibility for cartilage tissue engineering. Compos Sci Technol. 2015;106:76-84.

72. Shevach M, Fleischer S, Shapira A, Dvir T. Gold nanoparticledecellularized matrix hybrids for cardiac tissue engineering. Nano Lett. 2014;14(10):5792-5796

73. Shevach M, Maoz BM, Feiner R, et al. Nanoengineering gold particle composite fibers for cardiac tissue engineering. $J$ Mater Chem B. 2013;1(39):5210-5217.

74. Navaei A, Saini H, Christenson W, Sullivan RT, Ros R, Nikkhah M. Gold nanorod-incorporated gelatin-based conductive hydrogels for engineering cardiac tissue constructs. Acta Biomater. 2016;41:133-146.

75. Kharaziha M, Memic A, Akbari M, Brafman DA, Nikkhah M. Nano-enabled approaches for stem cell-based cardiac tissue engineering. Adv Healthc Mater. 2016;5(13):1533-1553.

76. Shin SR, Shin C, Memic A, et al. Aligned carbon nanotube-based flexible gel substrates for engineering biohybrid tissue actuators. $A d v$ Funct Mater. 2015;25(28):4486-4495.

77. Stout DA, Basu B, Webster TJ. Poly (lactic-co-glycolic acid): carbon nanofiber composites for myocardial tissue engineering applications. Acta Biomater. 2011;7(8):3101-3112.

78. Collier JH, Camp JP, Hudson TW, Schmidt CE. Synthesis and characterization of polypyrrole-hyaluronic acid composite biomaterials for tissue engineering applications. J Biomed Mater Res A. 2000;50(4):574-584.

79. Kim HS, Hobbs HL, Wang L, et al. Biocompatible composites of polyaniline nanofibers and collagen. Synth Met. 2009;159(13):1313-1318.

80. Sniadecki NJ, Anguelouch A, Yang MT, et al. Magnetic microposts as an approach to apply forces to living cells. Proc Natl Acad Sci U S A. 2007;104(37):14553-14558.

81. Stoimenov PK, Klinger RL, Marchin GL, et al. Metal oxide nanoparticles as bactericidal agents. Langmuir. 2002;18(17):6679-6686.

82. Samberg ME, Mente P, He T, King MW, Monteiro-Riviere NA. In vitro biocompatibility and antibacterial efficacy of a degradable poly (L-lactide-co-epsilon-caprolactone) copolymer incorporated with silver nanoparticles. Ann Biomed Eng. 2014;42(7):1482-1493.

83. Xing ZC, Chae WP, Baek JY, Choi MJ, Jung Y, Kang IK. In vitro assessment of antibacterial activity and cytocompatibility of silvercontaining PHBV nanofibrous scaffolds for tissue engineering. Biomacromolecules. 2010;11(5):1248-1253.
84. El Hajj F, Hasan A, Nakhleh J, et al. Nanosilver loaded GelMA hydrogel for antimicrobial coating of biomedical implants. Advances in Biomedical Engineering (ICABME), 2015 International Conference on. IEEE; 2015.

85. Kim JS, Kuk E, Yu KN, et al. Antimicrobial effects of silver nanoparticles. Nanomedicine. 2007;3(1):95-101.

86. Salah N, Habib SS, Khan ZH, et al. High-energy ball milling technique for $\mathrm{ZnO}$ nanoparticles as antibacterial material. Int J Nanomed. 2011;6:863.

87. Al-Amri S, Ansari MS, Rafique S, et al. Ni doped $\mathrm{CuO}$ nanoparticles: structural and optical characterizations. Curr Nanosci. 2015; 11(2):191-197.

88. Azam A, Ahmed AS, Oves M, Khan MS, Memic A. Size-dependent antimicrobial properties of $\mathrm{CuO}$ nanoparticles against Gram-positive and-negative bacterial strains. Int J Nanomed. 2012;7:3527.

89. Azam A, Ahmed AS, Oves M, Khan MS, Habib SS, Memic A. Antimicrobial activity of metal oxide nanoparticles against Gram-positive and Gram-negative bacteria: a comparative study. Int J Nanomed. 2012;7:6003.

90. SaravananS, NethalaS, Pattnaik S, Tripathi A,MoorthiA,SelvamuruganN Preparation, characterization and antimicrobial activity of a bio-composite scaffold containing chitosan/nano-hydroxyapatite/nano-silver for bone tissue engineering. Int J Biol Macromol. 2011;49(2):188-193.

91. Marsich E, Bellomo F, Turco G, Travan A, Donati I, Paoletti S. Nanocomposite scaffolds for bone tissue engineering containing silver nanoparticles: preparation, characterization and biological properties. J Mater Sci Mater Med. 2013;24(7):1799-1807.

92. Patrascu JM, Nedelcu IA, Sonmez M, et al. Composite scaffolds based on silver nanoparticles for biomedical applications. $J$ Nanomater. 2015;2015:3.

93. Madhavan RV, Rosemary MJ, Nandkumar MA, Krishnan KV, Krishnan LK. Silver nanoparticle impregnated poly ( $\varepsilon$-caprolactone) scaffolds: optimization of antimicrobial and noncytotoxic concentrations. Tissue Eng A. 2010;17(3-4):439-449.

94. Duraipandy N, Lakra R, Srivatsan KV, et al. Plumbagin caged silver nanoparticle stabilized collagen scaffold for wound dressing. J Mater Chem B. 2015;3(7):1415-1425.

95. Silver S. Bacterial silver resistance: molecular biology and uses and misuses of silver compounds. FEMS Microbiol Rev. 2003;27(2-3): 341-353.

96. Tran PA, Webster TJ. Selenium nanoparticles inhibit Staphylococcus aureus growth. Int J Nanomed. 2011;6:1553.

97. Ramos J, Tran P, Webster T. Selenium nanoparticles for the prevention of PVC-related medical infections. Bioengineering Conference (NEBEC), 2012 38th Annual Northeast. Philadelphia, PA: IEEE; 2012.

98. Taylor EN, Webster TJ. Multifunctional magnetic nanoparticles for orthopedic and biofilm infections. Int J Nanotechnol. 2010;8(1-2):21-35.

99. Mahmoudi M, Serpooshan V. Silver-coated engineered magnetic nanoparticles are promising for the success in the fight against antibacterial resistance threat. ACS Nano. 2012;6(3):2656-2664.

100. Park H, Park HJ, Kim JA, et al. Inactivation of Pseudomonas aeruginosa PA01 biofilms by hyperthermia using superparamagnetic nanoparticles. J Microbiol Methods. 2011;84(1):41-45.

101. Orr AW, Helmke BP, Blackman BR, Schwartz MA. Mechanisms of mechanotransduction. Dev Cell. 2006;10(1):11-20.

102. Tseng P, Judy JW, Di Carlo D. Magnetic nanoparticle-mediated massively parallel mechanical modulation of single-cell behavior. Nat Methods. 2012;9(11):1113-1119.

103. Mannix RJ, Kumar S, Cassiola F, et al. Nanomagnetic actuation of receptor-mediated signal transduction. Nat Nanotechnol. 2008; 3(1):36-40.

104. Gopinath P, Gogoi SK, Sanpui P, Paul A, Chattopadhyay A, Ghosh SS. Signaling gene cascade in silver nanoparticle induced apoptosis. Colloids Surf B Biointerfaces. 2010;77(2):240-245.

105. Pittenger MF, Mackay AM, Beck SC, et al. Multilineage potential of adult human mesenchymal stem cells. Science. 1999;284(5411): 143-147. 
106. Wang S, Castro R, An X, et al. Electrospun laponite-doped poly (lactic-co-glycolic acid) nanofibers for osteogenic differentiation of human mesenchymal stem cells. J Mater Chem. 2012;22(44): 23357-23367.

107. Ito A, Kamihira M. Tissue engineering using magnetite nanoparticles. Prog Mol Biol Transl Sci. 2011;104:355-395.

108. Scherer F, Anton M, Schillinger U, et al. Magnetofection: enhancing and targeting gene delivery by magnetic force in vitro and in vivo. Gene Ther. 2002;9(2):102.

109. Krötz F, Sohn HY, Gloe T, Plank C, Pohl U. Magnetofection potentiates gene delivery to cultured endothelial cells. J Vasc Res. 2003;40(5): 425-434.

110. Lee CH, Kim EY, Jeon K, et al. Simple, efficient, and reproducible gene transfection of mouse embryonic stem cells by magnetofection. Stem Cells Dev. 2008;17(1):133-142.

111. Ino K, Kawasumi T, Ito A, Honda H. Plasmid DNA transfection using magnetite cationic liposomes for construction of multilayered geneengineered cell sheet. Biotechnol Bioeng. 2008;100(1):168-176.

112. Neuberger T, Schöpf B, Hofmann H, et al. Superparamagnetic nanoparticles for biomedical applications: possibilities and limitations of a new drug delivery system. J Magn Magn Mater. 2005;293(1): 483-496.

113. Harris L, Goff JD, Carmichael AY, et al. Magnetite nanoparticle dispersions stabilized with triblock copolymers. Chem Mater. 2003; 15(6):1367-1377.

114. Dobson J. Gene therapy progress and prospects: magnetic nanoparticlebased gene delivery. Gene Ther. 2006;13(4):283-287.

115. Khan ZH, Ansari MS, Salah NA, et al. COBALT catalyzed-multiwalled carbon nanotubes film sensor for carbon mono-oxide gas. Dig J Nanomater Biostruct. 2011;6(4):1947.

116. Alshehri R, Ilyas AM, Hasan A, et al. Carbon nanotubes in biomedical applications: factors, mechanisms, and remedies of toxicity: miniperspective. J Med Chem. 2016;59(18):8149-8167.

117. Salah N, Al-Ghamdi A, Memic A, Habib SS, Khan ZH. Formation of carbon nanotubes from carbon-rich fly ash: growth parameters and mechanism. Mater Manuf Processes. 2016;31(2):146-156.

118. Salah N, Habib SS, Khan ZH, Memic A, Nahas MN. Growth of carbon nanotubes on catalysts obtained from carbon rich fly ash. Dig J Nanomater Biostructures. 2012;7(3):1279-1288.

119. Cai D, Mataraza JM, Qin ZH, et al. Highly efficient molecular delivery into mammalian cells using carbon nanotube spearing. Nat Methods. 2005;2(6):449-454.

120. Paul A, Hasan A, Rodes L, Sangaralingam M, Prakash S. Bioengineered baculoviruses as new class of therapeutics using micro and nanotechnologies: principles, prospects and challenges. Adv Drug Deliv Rev. 2014;71:115-130.

121. Ito A, Takahashi T, Kameyama Y, Kawabe Y, Kamihira M. Magnetic concentration of a retroviral vector using magnetite cationic liposomes. Tissue Eng C Methods. 2008;15(1):57-64.

122. Akiyama H, Ito A, Kawabe Y, Kamihira M. Cell-patterning using poly (ethylene glycol)-modified magnetite nanoparticles. J Biomed Mater Res A. 2010;92(3):1123-1130.

123. Gersting SW, Schillinger U, Lausier J, et al. Gene delivery to respiratory epithelial cells by magnetofection. J Gene Med. 2004;6(8): 913-922.

124. Krötz F, de Wit C, Sohn HY, et al. Magnetofection - a highly efficient tool for antisense oligonucleotide delivery in vitro and in vivo. $\mathrm{Mol}$ Ther. 2003;7(5):700-710.

125. Ino $\mathrm{K}$, Ito $\mathrm{A}$, Honda $\mathrm{H}$. Cell patterning using magnetite nanoparticles and magnetic force. Biotechnol Bioeng. 2007;97(5):1309-1317.

126. Shimizu K, Ito A, Arinobe M, et al. Effective cell-seeding technique using magnetite nanoparticles and magnetic force onto decellularized blood vessels for vascular tissue engineering. J Biosci Bioeng. 2007; 103(5):472-478.

127. Xu CY, Inai R, Kotaki M, Ramakrishna S. Aligned biodegradable nanofibrous structure: a potential scaffold for blood vessel engineering. Biomaterials. 2004;25(5):877-886.
128. Li WJ, Tuli R, Okafor C, et al. A three-dimensional nanofibrous scaffold for cartilage tissue engineering using human mesenchymal stem cells. Biomaterials. 2005;26(6):599-609.

129. Li C, Vepari C, Jin HJ, Kim HJ, Kaplan DL. Electrospun silk-BMP-2 scaffolds for bone tissue engineering. Biomaterials. 2006;27(16): 3115-3124.

130. Sill TJ, von Recum HA. Electrospinning: applications in drug delivery and tissue engineering. Biomaterials. 2008;29(13):1989-2006.

131. Feng ZQ, Chu X, Huang NP, et al. The effect of nanofibrous galactosylated chitosan scaffolds on the formation of rat primary hepatocyte aggregates and the maintenance of liver function. Biomaterials. 2009; 30(14):2753-2763.

132. Namgung S, Baik KY, Park J, Hong S. Controlling the growth and differentiation of human mesenchymal stem cells by the arrangement of individual carbon nanotubes. ACS Nano. 2011;5(9):7383-7390.

133. Teo BK, Wong ST, Lim CK, et al. Nanotopography modulates mechanotransduction of stem cells and induces differentiation through focal adhesion kinase. ACS Nano. 2013;7(6):4785-4798.

134. Lavenus S, Trichet V, Le Chevalier S, Hoornaert A, Louarn G, Layrolle P. Cell differentiation and osseointegration influenced by nanoscale anodized titanium surfaces. Nanomedicine. 2012;7(7):967-980.

135. Xu C, Sun S. New forms of superparamagnetic nanoparticles for biomedical applications. Adv Drug Deliv Rev. 2013;65(5):732-743.

136. Rheinwald J, Green H. Serial cultivation of strains of human epidermal keratinocytes in defined clonal and serum-free culture. $J$ Invest Dermatol. 1975;6:331-342.

137. Yamamoto Y, Ito A, Kato M, et al. Preparation of artificial skeletal muscle tissues by a magnetic force-based tissue engineering technique. J Biosci Bioeng. 2009;108(6):538-543.

138. Saxena AK, Marler J, Benvenuto M, Willital GH, Vacanti JP. Skeletal muscle tissue engineering using isolated myoblasts on synthetic biodegradable polymers: preliminary studies. Tissue Eng. 1999;5(6): 525-531.

139. Dennis RG, Kosnik PE 2nd, Gilbert ME, Faulkner JA. Excitability and contractility of skeletal muscle engineered from primary cultures and cell lines. Am J Physiol Cell Physiol. 2001;280(2):C288-C295.

140. Moon du G, Christ G, Stitzel JD, Atala A, Yoo JJ. Cyclic mechanical preconditioning improves engineered muscle contraction. Tissue Eng Part A. 2008;14(4):473-482.

141. Akiyama H, Ito A, Kawabe Y, Kamihira M. Genetically engineered angiogenic cell sheets using magnetic force-based gene delivery and tissue fabrication techniques. Biomaterials. 2010;31(6):1251-1259.

142. Sato M, Ito A, Akiyama H, Kawabe Y, Kamihira M. Effects of B-cell lymphoma 2 gene transfer to myoblast cells on skeletal muscle tissue formation using magnetic force-based tissue engineering. Tissue Eng A. 2012;19(1-2):307-315.

143. Ito $\mathrm{A}$, Takizawa $\mathrm{Y}, \mathrm{Honda} \mathrm{H}$, et al. Tissue engineering using magnetite nanoparticles and magnetic force: heterotypic layers of cocultured hepatocytes and endothelial cells. Tissue Eng. 2004;10(5-6):833-840.

144. Ito A, Jitsunobu H, Kawabe Y, Kamihira M. Construction of heterotypic cell sheets by magnetic force-based 3-D coculture of HepG2 and NIH3T3 cells. J Biosci Bioeng. 2007;104(5):371-378.

145. Barthes J, Özçelik H, Hindié M, Ndreu-Halili A, Hasan A, Vrana NE. Cell microenvironment engineering and monitoring for tissue engineering and regenerative medicine: the recent advances. Biomed Res Int. 2014;2014:921905.

146. Hasan A, Nurunnabi M, Morshed M, et al. Recent advances in application of biosensors in tissue engineering. Biomed Res Int. 2014;2014: 307519.

147. Thaxton CS, Rosi NL, Mirkin CA. Optically and chemically encoded nanoparticle materials for DNA and protein detection. MRS Bull. 2005;30(5):376-380.

148. Tansil NC, Gao Z. Nanoparticles in biomolecular detection. Nano Today. 2006;1(1):28-37.

149. Rosenthal SJ, Chang JC, Kovtun O, McBride JR, Tomlinson ID. Biocompatible quantum dots for biological applications. Chem Biol. 2011; 18(1):10-24 
150. Goldman ER, Medintz IL, Mattoussi H. Luminescent quantum dots in immunoassays. Anal Bioanal Chem. 2006;384(3):560-563.

151. Sharon E, Freeman R, Willner I. CdSe/ZnS quantum dots-Gquadruplex/hemin hybrids as optical DNA sensors and aptasensors. Anal Chem. 2010;82(17):7073-7077.

152. Hardman R. A toxicologic review of quantum dots: toxicity depends on physicochemical and environmental factors. Environ Health Perspect. 2006;114(2): 165

153. Ding H, Cheng LW, Ma YY, Kong JL, Xiong HM. Luminescent carbon quantum dots and their application in cell imaging. New $J$ Chem. 2013;37(8):2515-2520.

154. Zijlstra P, Orrit M. Single metal nanoparticles: optical detection, spectroscopy and applications. Rep Prog Phys. 2011;74(10):106401.

155. Newman J, Roberts J, Blanchard G. Optical organophosphate sensor based upon gold nanoparticle functionalized fumed silica gel. Anal Chem. 2007;79(9):3448-3454.

156. Agasti SS, Rana S, Park MH, Kim CK, You CC, Rotello VM. Nanoparticles for detection and diagnosis. Adv Drug Deliv Rev. 2010;62(3): 316-328.

157. Park SJ, Taton TA, Mirkin CA. Array-based electrical detection of DNA with nanoparticle probes. Science. 2002;295(5559):1503-1506.

158. Noor MR, Goyal S, Christensen SM, Iqbal SM. Electrical detection of single-base DNA mutation using functionalized nanoparticles. Appl Phys Lett. 2009;95(7):073703.

159. Cleuziou JP, Wernsdorfer W, Ondarçuhu T, Monthioux M. Electrical detection of individual magnetic nanoparticles encapsulated in carbon nanotubes. ACS Nano. 2011;5(3):2348-2355.

160. Ronkainen NJ, Halsall HB, Heineman WR. Electrochemical biosensors. Chem Soc Rev. 2010;39(5):1747-1763.

161. Suni II. Impedance methods for electrochemical sensors using nanomaterials. Trends Anal Chem. 2008;27(7):604-611.

162. Wang M, Wang L, Wang G, et al. Application of impedance spectroscopy for monitoring colloid Au-enhanced antibody immobilization and antibody-antigen reactions. Biosens Bioelectron. 2004;19(6): $575-582$.

163. Li C-Z, Liu Y, Luong JH. Impedance sensing of DNA binding drugs using gold substrates modified with gold nanoparticles. Anal Chem. 2005;77(2):478-485.

164. Cui R, Pan HC, Zhu JJ, Chen HY. Versatile immunosensor using CdTe quantum dots as electrochemical and fluorescent labels. Anal Chem. 2007;79(22):8494-8501.

165. Li H, Sun Z, Zhong W, Hao N, Xu D, Chen HY. Ultrasensitive electrochemical detection for DNA arrays based on silver nanoparticle aggregates. Anal Chem. 2010;82(13):5477-5483.

166. Sirivisoot S, Webster TJ. Multiwalled carbon nanotubes enhance electrochemical properties of titanium to determine in situ bone formation. Nanotechnology. 2008;19(29):295101.
167. Pelletier DA, Suresh AK, Holton GA, et al. Effects of engineered cerium oxide nanoparticles on bacterial growth and viability. Appl Environ Microbiol. 2010;76(24):7981-7989.

168. Soleymani L Fang Z, Sargent EH, Kelley SO. Programming the detection limits of biosensors through controlled nanostructuring. Nat Nanotechnol. 2009;4(12):844-848.

169. Pagliari F, Mandoli C, Forte G, et al. Cerium oxide nanoparticles protect cardiac progenitor cells from oxidative stress. ACS Nano. 2012;6(5):3767-3775.

170. Santos GM, de Santi Ferrara FI, Zhao G, Rodrigues DF, Shih W. Photothermal inactivation of heat-resistant bacteria on nanoporous gold disk arrays. Opt Mater Express. 2016;6(4):1217-1229.

171. Feng Z, Gunsolus IL, Qiu TA, et al. Impacts of gold nanoparticle charge and ligand type on surface binding and toxicity to Gram-negative and Gram-positive bacteria. Chem Sci. 2015;6(9):5186-5196.

172. Shimizu K, Ito A, Yoshida T, Yamada Y, Ueda M, Honda H. Bone tissue engineering with human mesenchymal stem cell sheets constructed using magnetite nanoparticles and magnetic force. $J$ Biomed Mater Res B Appl Biomater. 2007;82(2):471-480.

173. Lee JH, Huh YM, Jun YW, et al. Artificially engineered magnetic nanoparticles for ultra-sensitive molecular imaging. Nat Med. 2007;13(1):95-99.

174. Ito A, Kamihira M. Tissue Engineering Using Magnetite Nanoparticles. In: Antonio V (editor). Progress in Molecular Biology and Translational Science. Academic Press; 2011:355-395.

175. Cezar CA, Kennedy SM, Mehta M, et al. Biphasic ferrogels for triggered drug and cell delivery. Adv Healthc Mater. 2014;3(11):1869-1876.

176. Corchero JL, Villaverde A. Biomedical applications of distally controlled magnetic nanoparticles. Trends Biotechnol. 2009;27(8): 468-476.

177. Tseng H, Gage JA, Raphael RM, et al. Assembly of a three-dimensional multitype bronchiole coculture model using magnetic levitation. Tissue Eng Part C Methods. 2013;19(9):665-675.

178. Liu W, Li Y, Feng S, et al. Magnetically controllable 3D microtissues based on magnetic microcryogels. Lab Chip. 2014; 14(15):2614-2625.

179. Li L, Zhao H, Chen Z, Mu X, Guo L. Aptamer-based electrochemical approach to the detection of thrombin by modification of gold nanoparticles. Anal Bioanal Chem. 2010;398(1):563-570.

180. Wang J, Liu G, Merkoçi A. Electrochemical coding technology for simultaneous detection of multiple DNA targets. J Am Chem Soc. 2003;125(11):3214-3215.

181. Doria G, Conde J, Veigas B, et al. Noble metal nanoparticles for biosensing applications. Sensors (Basel). 2012;12(2):1657-1687.
International Journal of Nanomedicine

\section{Publish your work in this journal}

The International Journal of Nanomedicine is an international, peerreviewed journal focusing on the application of nanotechnology in diagnostics, therapeutics, and drug delivery systems throughout the biomedical field. This journal is indexed on PubMed Central, MedLine, CAS, SciSearch $\AA$, Current Contents ${ }^{\circledR} /$ Clinical Medicine,

\section{Dovepress}

Journal Citation Reports/Science Edition, EMBase, Scopus and the Elsevier Bibliographic databases. The manuscript management system is completely online and includes a very quick and fair peer-review system, which is all easy to use. Visit http://www.dovepress.com/ testimonials.php to read real quotes from published authors. 